\title{
Taxonomic Significance of Electrophoretic Comparison of Enzymes in the Genera Rhodotorula and Rhodosporidium
}

\author{
M. YAMAZAKI AND K. KOMAGATA \\ Institute of Applied Microbiology, University of Tokyo, Bunkyo-ku, Tokyo 113, Japan
}

\begin{abstract}
We used polyacrylamide slab gel electrophoresis with specific staining for seven enzymes to compare 108 strains belonging to the genera Rhodotorula and Rhodosporidium. The patterns obtained allowed us to divide the strains of Rhodotorula glutinis and its varieties into six groups. The strains of Rhodotorula rubra and Rhodotorula pilimanae examined had identical patterns. Rhodotorula minuta var. minuta and Rhodotorula minuta var. texensis clearly differed from Rhodotorula glutinis and Rhodotorula rubra in their hexokinase and 6-phosphogluconate dehydrogenase patterns. Rhodotorula marina, Rhodotorula pallida, and Rhodotorula lactosa each had a characteristic pattern. We found three haploid mating type strains to mating type a of Rhodosporidium toruloides, mating type a of Rhodosporidium sphaerocarpum, and mating type $\alpha$ of Rhodosporidium diobovatum among the strains of Rhodotorula glutinis var. rufusa, Rhodotorula glutinis var. salinaria, and Rhodotorula glutinis var. glutinis by performing conjugation tests to confirm the relationships that were revealed when the enzyme patterns were compared. In the genus Rhodosporidium, compatible mating type strains showed similar enzymatic patterns. Strains of $R$ hodosporidium toruloides which could not assimilate potassium nitrate had the same enzymatic patterns as those that could.
\end{abstract}

Morphological and physiological characteristics have been used to classify and identify the yeasts and yeastlike organims, but the problems of using such properties have been described by Phaff and Price (38). Recently, information useful in yeast taxonomy has been reported in the areas of serology (47), proton magnetic resonance spectra of cell wall mannans (12), base compositions of deoxyribonucleic acids (DNA) (30), coenzyme Q systems (51), and DNA-DNA hybridizations (7).

The electrophoretic patterns (zymograms) of various enzymes are considered to be useful tools in the taxonomy of plants (5), animals $(25,36$, $42)$, and microorganisms $(4,35,53)$. It is thought that zymograms reflect minor structural differences at the molecular level and that similarities in enzyme systems reflect the relatedness of organisms. However, this technique has been used little in yeast taxonomy until now. Electrophoretic analyses of enzymes have been reported for some Candida species $(6,40)$ and for Cryptococcus laurentii (3).

The sexual state of a Rhodotorula species was first reported by Banno (1) in 1963; he observed a basidiomycetous life cycle in strains of $R h o$ dotorula glutinis after conjugation of two strains. Banno (2) described the genus Rhodosporidium and the species Rhodosporidium toruloides for this teleomorph. Later, Newell and
Fell (33) described Rhodosporidium sphaerocarpum, and six Rhodosporidium species were described by Fell (10), Newell and Hunter (34), and Fell et al. (11).

Nakase and Komagata (31) reported that the guanine-plus-cytosine $(\mathrm{G}+\mathrm{C})$ contents of the DNAs of Rhodotorula strains range from 50.0 to $68.5 \mathrm{~mol} \%$, and they classified these strains into four groups on the basis of their $\mathrm{G}+\mathrm{C}$ contents. Yamada and Kondo (52) reported that the coenzyme $\mathbf{Q}$ systems of Rhodotorula species are $\mathrm{Q}_{8}$, $Q_{9}$, or $Q_{10}$. This study revealed that these yeasts should be related to heterobasidiomycetes rather than to ascomycetes and that cytological and biochemical characteristics would be useful in the classification of asporogenous yeasts.

In this investigation we compared the enzymes of Rhodotorula strains with the enzymes of Rhodosporidium strains and applied the results to the classification of these genera.

\section{MATERIALS AND METHODS}

Yeast strains. We used 64 strains representing 12 species and six varieties in the genus Rhodotorula and 44 strains representing eight species in the genus $R$ hodosporidium. The sources of these strains are shown in Table 1 . We confirmed the identities of all of these strains by the methods of van der Walt (48). The designations for the mating types are the designations used in the original reports. 
TABLE 1. Strains of Rhodotorula and Rhodosporidium used in this study

\begin{tabular}{|c|c|c|c|}
\hline Species or variety & Strain & Source $^{a}$ & Reference \\
\hline \multirow[t]{2}{*}{ Rhodotorula aurantiaca } & YK 100 & IFO 0754 & \\
\hline & YK 101 & IFO 0758 & \\
\hline \multirow[t]{14}{*}{ Rhodotorula glutinis var. glutinis } & YK 102 & IFO 0414 & \\
\hline & YK 103 & IAM 4988 & \\
\hline & YK 104 & IFO 0688 & \\
\hline & YK 105 & IAM 12263 & \\
\hline & YK 106 & IFO 0697 & \\
\hline & YK 107 & IFO 1099 & \\
\hline & YK 108 & IFO 0667 & \\
\hline & YK 109 & FC 16 & 45 \\
\hline & YK 110 & CCY 20-14-2 & \\
\hline & YK 111 & RIFY & \\
\hline & YK 112 & H 3-9-1 & 15 \\
\hline & YK 113 & H 3-9-2 & 15 \\
\hline & YK 114 & $\mathrm{KC} \mathrm{4-4}$ & 45 \\
\hline & YK 115 & $\mathrm{KC} 9$ & 45 \\
\hline Rhodotorula glutinis var. dairenensis & YK 116 & IAM 12228 & \\
\hline Rhodotorula glutinis var. rufusa & YK 117 & AY 28 & 16 \\
\hline Rhodotorula glutinis var. salinaria & YK 118 & IFO 1438 & \\
\hline \multirow[t]{3}{*}{ Rhodotorula graminis } & YK 119 & IFO 0190 & \\
\hline & YK 120 & K 1-1 & 44 \\
\hline & YK 121 & CCY 20-14-1 & \\
\hline \multirow[t]{3}{*}{ Rhodotorula lactosa } & YK 122 & IAM 12229 & \\
\hline & YK 123 & IAM 12230 & \\
\hline & YK 124 & IFO 1058 & \\
\hline Rhodotorula marina & YK 125 & IFO 0928 & \\
\hline \multirow[t]{5}{*}{ Rhodotorula minuta var. minuta } & YK 126 & IFO 0387 & \\
\hline & YK 127 & IAM 12233 & \\
\hline & YK 128 & IFO 1434 & \\
\hline & YK 129 & CBS 5695 & \\
\hline & YK 130 & AY 24 & 16 \\
\hline \multirow[t]{7}{*}{ Rhodotorula minuta var. texensis } & YK 131 & IFO 0932 & \\
\hline & YK 132 & IFO 0879 & \\
\hline & YK 133 & IFO 1006 & \\
\hline & YK 134 & IFO 1102 & \\
\hline & YK 135 & IFO 0920 & \\
\hline & YK 136 & IAM 12231 & \\
\hline & YK 137 & NP $2-10$ & 14 \\
\hline \multirow[t]{3}{*}{ Rhodotorula pallida } & YK 138 & IFO 0715 & \\
\hline & YK 159 & CBS 2408 & \\
\hline & YK 160 & CBS 5475 & \\
\hline \multirow[t]{2}{*}{ Rhodotorula pilimanae } & YK 139 & AJ 5217 & \\
\hline & YK 140 & CCY 20-15-1 & \\
\hline \multirow[t]{15}{*}{ Rhodotorula rubra } & YK 141 & IAM 4989 & \\
\hline & YK 142 & IFO 1100 & \\
\hline & YK 143 & AY 2 & 16 \\
\hline & YK 144 & IAM 12232 & \\
\hline & YK 145 & IFO 0894 & \\
\hline & YK 146 & IFO 0870 & \\
\hline & YK 147 & MY 19 & 17 \\
\hline & YK 148 & MY 84 & 17 \\
\hline & YK 149 & NP 2-17-4B & 14 \\
\hline & YK 150 & IFO 0890 & \\
\hline & YK 151 & IFO 0909 & \\
\hline & YK 152 & IFO 0892 & \\
\hline & YK 153 & AY 31 & 16 \\
\hline & YK 154 & A 16 & 13 \\
\hline & YK 156 & I 6-1 & \\
\hline \multirow[t]{2}{*}{ Rhodotorula araucariae } & YK 161 & CBS 6031 & \\
\hline & YK 162 & CBS 5143 & \\
\hline \multirow{2}{*}{ Rhodotorula acheniorum } & YK 163 & CBS 6384 & \\
\hline & YK 164 & CBS 6386 & \\
\hline
\end{tabular}


TABLE 1-Continued

\begin{tabular}{|c|c|c|c|}
\hline Species or variety & Strain & Source $^{a}$ & Reference \\
\hline Rhodotorula sinensis & YK 165 & CBS 6962 & \\
\hline \multirow{20}{*}{ Rhodosporidium toruloides } & YK 200 & IAM 12254 (mating type A) & \\
\hline & YK 201 & IFO 0559 (mating type A) & \\
\hline & YK 202 & IFO 0413 (mating type A) & \\
\hline & YK 203 & CCY $62-3-3$ (mating type A) & \\
\hline & YK 204 & GSB $20-2-15$ (mating type A) & \\
\hline & YK 205 & GSB $20-2-16$ (mating type A) & \\
\hline & YK 206 & IFO 0871 (mating type A) & \\
\hline & YK 207 & GSB G-5 (mating type A) & \\
\hline & YK 208 & GSB G-8 (mating type A) & \\
\hline & YK 209 & GSB G-27 (mating type A) & \\
\hline & YK 210 & GSB G-29 (mating type A) & \\
\hline & YK 211 & IAM 12256 (mating type a) & \\
\hline & YK 212 & IFO 1236 (mating type a) & \\
\hline & YK 213 & CCY $62-2-20$ (mating type a) & \\
\hline & YK 214 & GSB G-32 (mating type a) & \\
\hline & YK 215 & GSB Rg-1 (mating type a) & \\
\hline & YK 216 & IFO 1638 (mating type a) & \\
\hline & YK 217 & CCY $62-2-18$ (self-sporulating) & \\
\hline & YK 218 & CCY 62-3-1 (self-sporulating) & \\
\hline & YK 219 & CCY $62-3-2$ (self-sporulating) & \\
\hline \multirow[t]{3}{*}{ Rhodosporidium sphaerocarpum } & YK 220 & IAM 12261 (mating type a) & \\
\hline & YK 221 & IAM 12262 (mating type $\alpha$ ) & \\
\hline & YK 222 & CCY 62-1-1 (self-sporulating) & \\
\hline \multirow[t]{4}{*}{ Rhodosporidium diobovatum } & YK 223 & IAM 12259 (mating type a) & \\
\hline & YK 224 & IFO 1828 (mating type a) & \\
\hline & YK 225 & IAM 12260 (mating type $\alpha$ ) & \\
\hline & YK 226 & IFO 1830 (mating type $\alpha$ ) & \\
\hline \multirow{2}{*}{ Rhodosporidium malvinellum } & YK 227 & CCY $62-4-1$ (mating type $\alpha$ ) & \\
\hline & YK 228 & CCY 62-4-2 (mating type a) & \\
\hline \multirow[t]{2}{*}{ Rhodosporidium capitatum } & YK 229 & ATCC 24507 (self-sporulating) & \\
\hline & YK 230 & ATCC 24508 (self-sporulating) & \\
\hline \multirow[t]{5}{*}{ Rhodosporidium dacryoidum } & YK 231 & CBS 6353 (mating type A1B1) & \\
\hline & YK 232 & CBS 6354 (mating type A2B2) & \\
\hline & YK 233 & CBS 6355 (mating type A2B1) & \\
\hline & YK 234 & CBS 6356 (mating type A1B2) & \\
\hline & YK 235 & CBS 6357 (Amut Bx) & \\
\hline \multirow[t]{4}{*}{ Rhodosporidium bisporidiis } & YK 236 & CBS 6346 (mating type A1B1) & \\
\hline & YK 237 & CBS 6347 (mating type A2B2) & \\
\hline & YK 238 & CBS 6348 (mating type A1B2) & \\
\hline & YK 239 & CBS 6349 (mating type A2B1) & \\
\hline \multirow{4}{*}{ Rhodosporidium infirmo-miniatum } & YK 240 & IFO 1057 (mating type A1) & \\
\hline & YK 241 & CBS 6350 (mating type A2) & \\
\hline & YK 242 & CBS 6352 (mating type A3) & \\
\hline & YK 243 & IFO 1378 & \\
\hline
\end{tabular}

${ }^{a}$ Abbreviations: IAM, Institute of Applied Microbiology, University of Tokyo, Tokyo, Japan; IFO, Institute for Fermentation, Osaka, Japan; CCY, Czechoslovak Collection of Yeasts, Bratislava, Czechoslovakia; AJ, Central Research Laboratories, Ajinomoto Co., Inc., Kawasaki, Japan; CBS, Centraalbureau voor Schimmelcultures, Delft, The Netherlands; ATCC, American Type Culture Collection, Rockville, Md.; RIFY, Research Institute of Fermentation, Yamanashi University, Kofu, Japan.

Cultivation and harvest of cells. The culture medium used contained $3 \mathrm{~g}$ of yeast extract, $20 \mathrm{~g}$ of glucose, $5 \mathrm{~g}$ of $\left(\mathrm{NH}_{4}\right)_{2} \mathrm{SO}_{4}, 0.5 \mathrm{~g}$ of $\mathrm{K}_{2} \mathrm{HPO}_{4}, 0.5 \mathrm{~g}$ of $\mathrm{Na}_{2} \mathrm{HPO}_{4}, 1$ of $\mathrm{MgSO}_{4} \cdot 7 \mathrm{H}_{2} \mathrm{O}$, and $1,000 \mathrm{ml}$ of deionized water; the $\mathrm{pH}$ of this medium was 7.2 . The yeasts were cultivated in $500-\mathrm{ml}$ flasks containing $200 \mathrm{ml}$ of medium; incubation was for $24 \mathrm{~h}$ at 20 or $27^{\circ} \mathrm{C}$ with shaking. The cells were harvested by centrifugation at $4,500 \times g$ for $5 \mathrm{~min}$ at a low temperature and were washed with $0.05 \mathrm{M}$ tris(hydroxymethyl)amino- methane hydrochloride buffer $(\mathrm{pH} 7.8$ ). The harvested cells were stored in a freezer at $-20^{\circ} \mathrm{C}$ until they were used.

Preparation of cell-free extracts for electrophoresis. Cells were disrupted with a mechanical cell homogenizer (B. Braun, Melsungen, Germany). The frozen cells of each culture were suspended in 1 to 2 volumes of $0.05 \mathrm{M}$ tris(hydroxymethyl)aminomethane hydrochloride buffer ( $\mathrm{pH} 7.8$ ) and were transferred to a 50 - or $70-\mathrm{ml}$ glass vessel containing glass beads 
(diameter, 0.45 to $0.5 \mathrm{~mm}$ ). The cells were cooled in ice and then were disrupted for 4 to $8 \mathrm{~min}$ at 4,000 cycles per min, cooling with carbon dioxide. Disruption of cells was confirmed microscopically. After more than $50 \%$ of the cells were disrupted, the glass beads were removed from the homogenate. Insoluble debris and undisrupted cells were removed by centrifugation at $24,000 \times g$ and $5^{\circ} \mathrm{C}$. The supernatant fluid was used directly as an enzyme source for electrophoretic analyses and was stored in a freezer at $-20^{\circ} \mathrm{C}$ until just before use.

Gel slab electrophoresis. A type SJ-1060 SDH electrophoretic apparatus (ATTO Co., Ltd.) was used for vertical gel slab electrophoresis; this apparatus provided a slab $2 \mathrm{~mm}$ thick. A 3.0\% large-pore upper gel and a 7.5\% small-pore separation gel were prepared by the method of Davis (9), and 12 individual slots were available at one time. Tris(hydroxymethyl)aminomethane-glycine buffer $(\mathrm{pH} 8.3)$ was used as the electrode buffer, and bromophenol blue was used as the tracking dye. Usually, an enzyme preparation from Rhodotorula glutinis var. glutinis YK 105 (IAM 12263) was used as a reference. Gel electrophoresis was performed at a regulated current of 15 to $20 \mathrm{~mA}$ / gel slab for 6 to $8 \mathrm{~h}$ at $5^{\circ} \mathrm{C}$. After electrophoresis, the gel slab was removed from the gel mold and was stained to visualize the enzymes.

Staining procedures. We studied the following seven enzymes: fructose-1,6-bisphosphate aldolase (FA; EC 4.1.2.13), 6-phosphogluconate dehydrogenase (6PGDH; EC 1.1.1.41), malate dehydrogenase (MDH; EC 1.1.1.37; nicotinamide adenine dinucleotide dependent), hexokinase (HK; EC 2.7.1.1), phosphoglucomutase (PGm; EC 2.7.5.1), glucose-6-phosphate dehydrogenase (G6PDH; EC 1.1.1.49), and glutamate dehydrogenase (GDH; EC 1.4.1.4). These enzymes were chosen because they play important roles in the metabolism of glucose by yeasts. The staining procedures used for these enzymes have been described by Siciliano and Shaw (41). After staining, the gels were dried under a vacuum with warming, and the relative mobilities $\left(R_{m}\right)$ of the enzyme bands were calculated as the ratio of the distance that the enzyme moved from the origin to the distance that the tracking dye moved.

\section{RESULTS}

Figure 1 shows 6PGDH electrophoretic patterns for some strains of Rhodotorula and Rhodosporidium species, and Fig. 2 shows patterns for representative strains of these two genera diagrammatically. Tables 2 through 5 present data on the $R_{m}$ values for seven enzymes from the yeasts tested. The FA, 6PGDH, MDH, and HK patterns were characteristic for each species. Several species had identical PGm and G6PDH patterns. GDH showed small $R_{m}$ values, and clear differences between species were not detected. MDH produced several enzymatic bands, HK, PGm, and G6PDH produced one or two bands, and FA, 6PGDH, and GDH produced a single band.
Electrophoretic comparison of Rhodosporidium species. The Rhodosporidium toruloides strains tested produced two different zymograms for each enzyme; that is, FA had an $R_{m}$ of 0.43 or $0.48, \mathrm{G} 6 \mathrm{PDH}$ had an $R_{m}$ of 0.24 or 0.26 , GDH had an $R_{m}$ of 0.12 or 0.13 , and MDH had $R_{m}$ values of $0.16,0.20,0.22$, and 0.25 or 0.16 , 0.20 , and 0.31 . However, 6PGDH produced only one band $\left(R_{m}, 0.33\right.$ to 0.34$)$ (Table 2). FA with an $R_{m}$ of 0.48 was found in strains YK 214, YK 215 , and YK 216, which produced pseudomycelia. Strain YK 216 was once named Rhodotorula glutinis var. rufusa (24). It is interesting that the only strains producing FA with an $R_{m}$ of 0.48 produced pseudomycelia. Strains YK 217, YK 218 , and YK 219 were received as self-sporulating strains of Rhodosporidium toruloides (27). The enzymes of YK 217 were similar to the enzymes of strains of both mating types $A$ and a, but the enzymes of YK 218 and YK 219 were not. However, on the whole, the strains of mating types $\mathrm{A}$ and a showed similar patterns for their respective enzymes.

Three Rhodosporidium sphaerocarpum strains, including the self-sporulating strain, produced identical patterns for FA, 6PGDH, HK, PGm, G6PDH, and GDH (Table 2).

Of the four Rhodosporidium diobovatum strains tested, YK 223, YK 225, and YK 226 showed identical patterns for FA, 6PGDH, $\mathrm{MDH}, \mathrm{HK}, \mathrm{G6PDH}$, and GDH, and YK 224 was

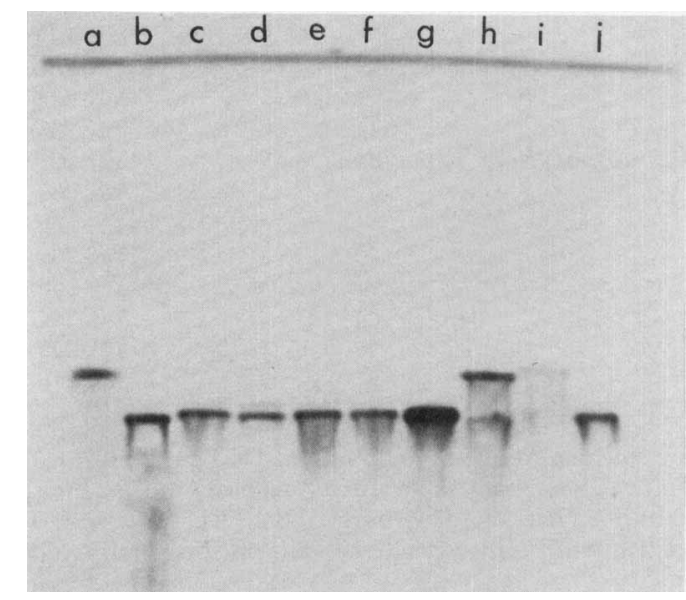

FIG. 1. Polyacrylamide gel stained for 6PGDH. Lane a, Rhodotorula glutinis var. glutinis YK 105; lane b, Rhodosporidium toruloides YK 201 (mating type A); lane c, strain YK 206 (mating type A); lane $d$, strain YK 200 (mating type A); lane e, YK 211 (mating type a); lane f, strain YK 212 (mating type a); lane g, strain YK 216 (mating type a); lane $h$, Rhodotorula glutinis var. dairenensis YK 116; lane $i$, Rhodotorula glutinis var. salinaria YK 118; lane j, Rhodotorula glutinis var. rufusa YK 117. 
similar to the above-mentioned strains with respect to FA and PGm but showed slight variations in its MDH, HK, and GDH patterns and a different G6PDH pattern (Table 2).

Both mating type strains of Rhodosporidium malvinellum tested produced identical patterns for FA, 6PGDH, MDH, PGm, G6PDH, and GDH but a different pattern for HK (Table 2).

Four Rhodosporidium bisporidiis strains, each representing one of the four mating types, showed identical patterns for all seven enzymes and were similar to Rhodosporidium diobovatum strains YK 223, YK 224, YK 225, and YK 226 with respect to their FA, $6 \mathrm{PGDH}, \mathrm{MDH}$, PGm, and GDH patterns. In addition, strain YK 224 was similar to four strains of Rhodosporidium bisporidiis with respect to $\mathrm{HK}$ and G6PDH (Table 2).

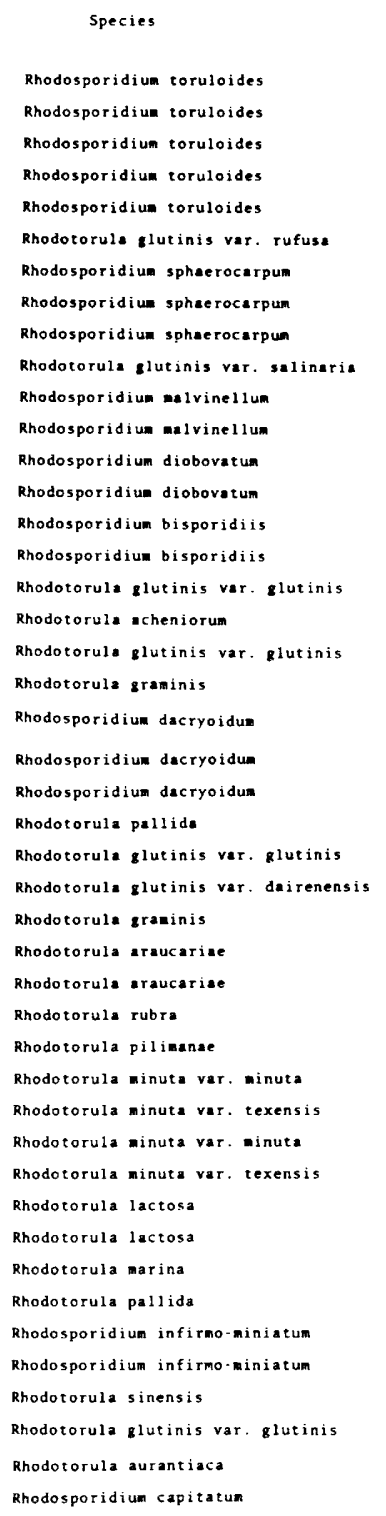

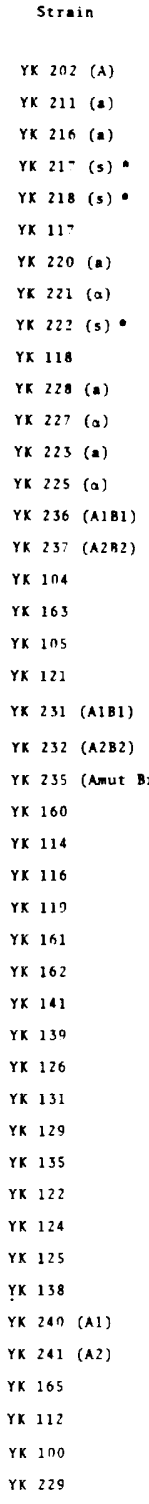

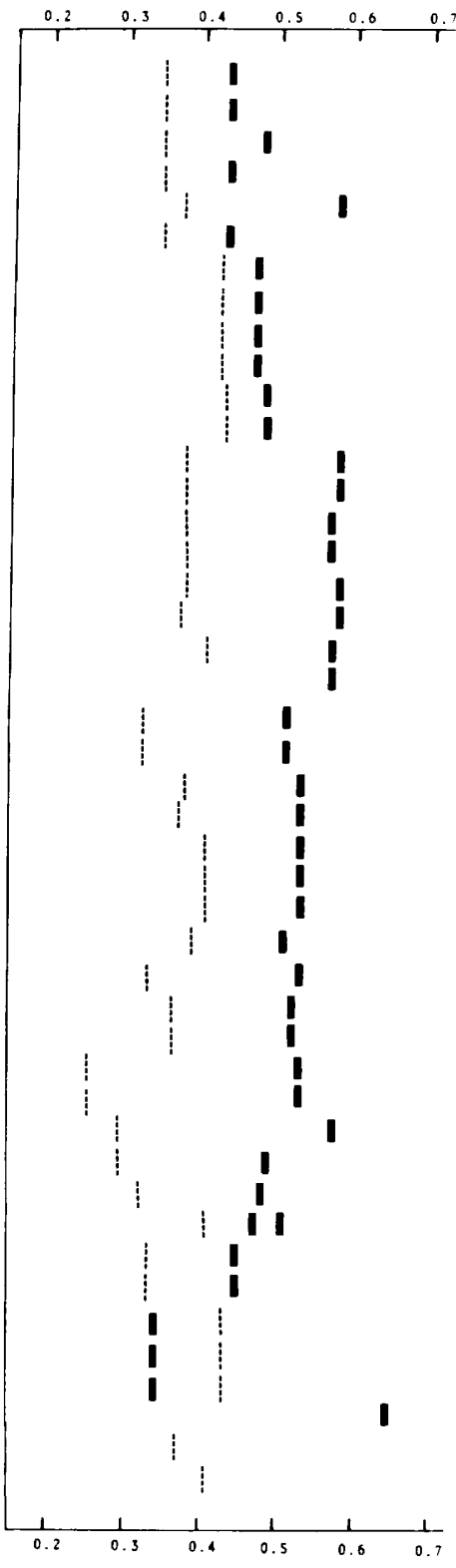

Relative mobility (Rm)

FIG. 2. Diagrammatic illustration of the FA and 6PGDH patterns for representative Rhodotorula and Rhodosporidium strains. Asterisks indicate self-sporulating strains. Solid lines, FA; dashed lines, 6PGDH. 


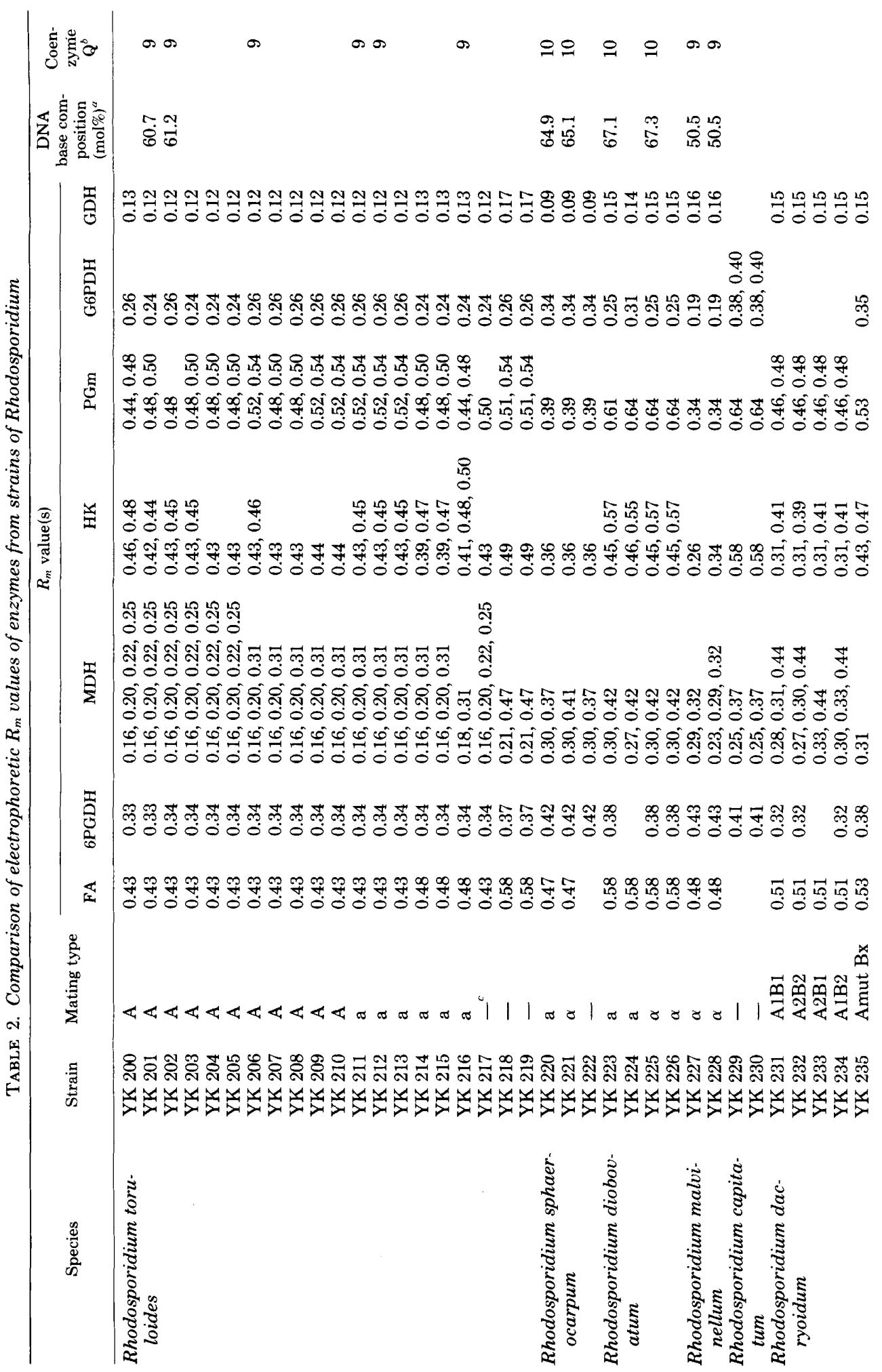




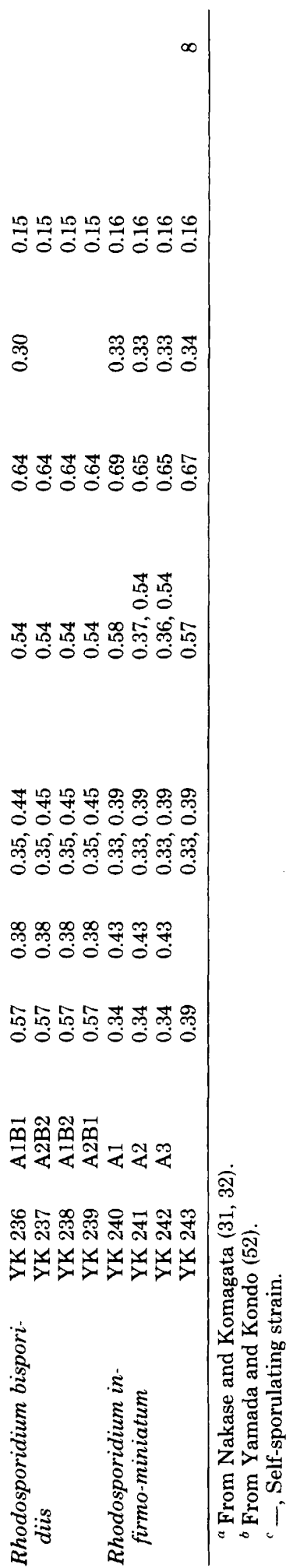

Of the five Rhodosporidium dacryoidum strains tested, four (each representing one of the four mating types) showed identical patterns for all seven enzymes, but YK 235, which was believed to be a mutant, differed from the other strains in its FA, 6PGDH, MDH, HK, and PGm patterns (Table 2).

Of four Rhodosporidium infirmo-miniatum strains, (strains YK 240, YK 241, and YK 242; representing the three known mating types; multiallelic bipolar) produced exhibited similar FA, 6PGDH, MDH, G6PDH, and GDH patterns, but there were slight variations in the $\mathrm{HK}$ and PGm patterns. Strain YK 243, whose mating type was not confirmed, showed a pattern which was similar to the patterns of above-mentioned strains with respect to GDH but different with respect to FA. The patterns of the other enzymes showed slight variations (Table 2).

The two strains of Rhodosporidium capitatum tested exhibited identical patterns for all enzymes (Table 2).

Electrophoretic comparison of Rhodotorula species. Strains of Rhodotorula glutinis and its varieties were classified into six groups on the basis of their FA and 6PGDH patterns (Table 3). The strains in group 1 produced FA with an $R_{m}$ of 0.58 and 6 PGDH with $R_{m}$ values of 0.37 to 0.38; YK 102, YK 103, and YK 104 were included in this group. Members of group 2 produced FA with an $R_{m}$ of 0.53 and 6 PGDH with an $R_{m}$ of 0.41 ; YK 114, YK 115, and Rhodotorula glutinis var. dairenensis YK 116 were included in this group. The strains in group 3 produced FA with an $R_{m}$ of 0.65 , but 6PGDH was not detected; YK 112 and YK 113 were included in this group. The FA and HK patterns for strains in this group differed from the FA and HK patterns of other Rhodotorula strains. Members of group 4 produced FA with an $R_{m}$ of 0.57 to 0.58 and $6 \mathrm{PGDH}$ with an $R_{m}$ of 0.41 to 0.42 ; YK 105, YK 106, YK 107, YK 108, YK 109, YK 110, and YK 111 were included in this group. Rhodotorula glutinis var. rufusa YK 117 belonged to group 5, and Rhodotorula glutinis var. salinaria YK 118 belonged to group 6 .

Rhodotorula minuta var. minuta and Rhodotorula minuta var. texensis had very similar enzyme patterns and were classified into four groups on the basis of their FA and 6PGDH patterns (Table 4). Members of group 1 produced FA with an $R_{m}$ of 0.53 and 6PGDH with an $R_{m}$ of 0.25 ; Rhodotorula minuta var. minuta strains YK 126 and YK 127 and Rhodotorula minuta var. texensis strains YK 131, YK 132, YK 133, and YK 134 were included in this group. Strains in group 2 produced FA with an $R_{m}$ of 0.57 and 6 PGDH with an $R_{m}$ of 0.29 ; Rhodoto- 


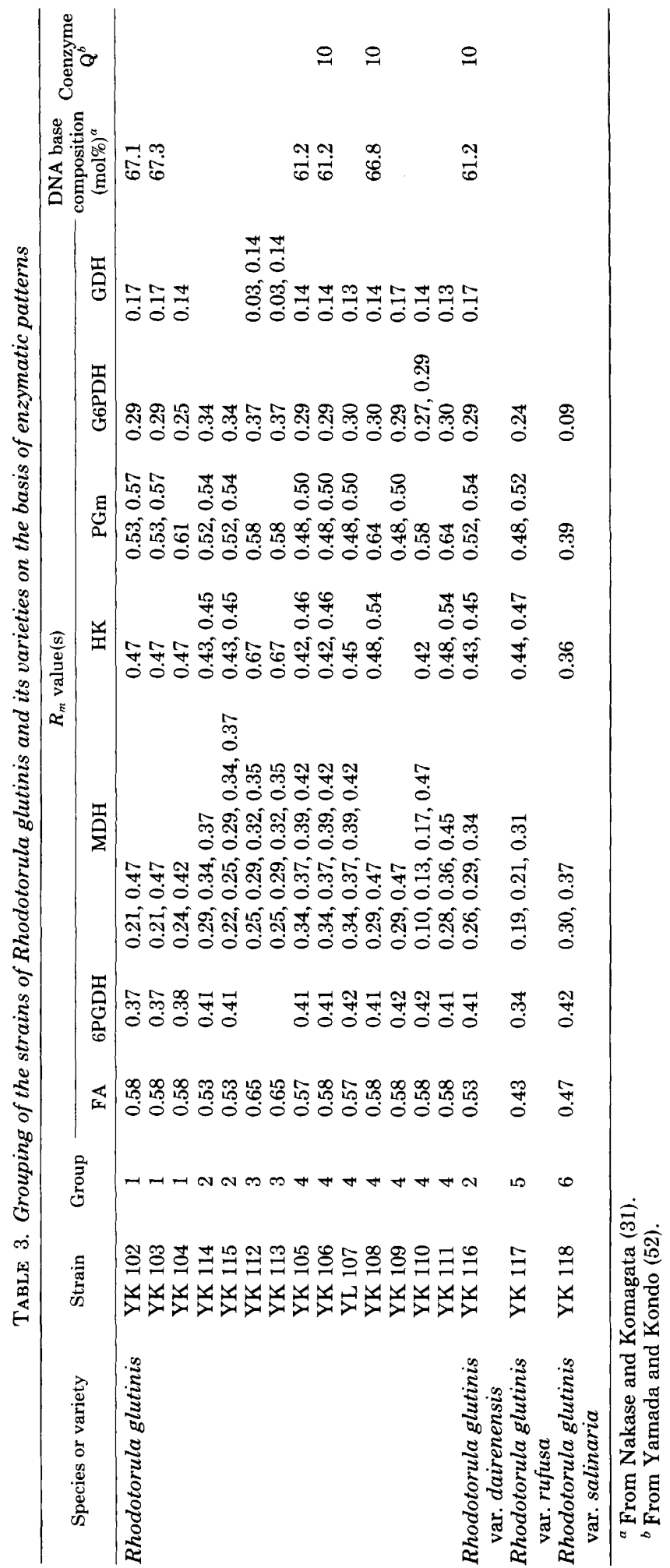


TABLE 4. Grouping of Rhodotorula minuta var. minuta and Rhodotorula minuta var. texensis strains on the basis of enzymatic patterns

\begin{tabular}{|c|c|c|c|c|c|c|c|c|c|c|c|}
\hline \multirow{2}{*}{ Variety } & \multirow{2}{*}{ Strain } & \multirow{2}{*}{ Group } & \multicolumn{7}{|c|}{$R_{m}$ value(s) } & \multirow{2}{*}{$\begin{array}{l}\text { DNA } \\
\text { base } \\
\text { composi- } \\
\text { tion } \\
(\mathrm{mol} \%)^{a}\end{array}$} & \multirow{2}{*}{$\begin{array}{c}\text { Coen- } \\
\text { zyme } \mathbf{Q}^{b}\end{array}$} \\
\hline & & & FA & 6PGDH & $\mathrm{MDH}$ & HK & PGm & G6PDH & GDH & & \\
\hline \multirow{5}{*}{$\begin{array}{l}\text { Rhodotorula } \\
\quad \text { minuta var. } \\
\text { minuta }\end{array}$} & YK 126 & 1 & 0.53 & 0.25 & $0.19,0.31$ & $0.26,0.38$ & 0.43 & 0.25 & 0.14 & 51.0 & \multirow[t]{2}{*}{10} \\
\hline & YK 127 & 1 & 0.53 & 0.25 & $0.19,0.31$ & 0.29 & 0.43 & 0.25 & 0.14 & 50.5 & \\
\hline & YK 128 & 4 & 0.53 & 0.30 & $0.15,0.32$ & $0.26,0.46$ & $0.48,0.50$ & 0.24 & & 50.7 & \multirow[t]{3}{*}{10} \\
\hline & YK 129 & 2 & 0.57 & 0.29 & $0.19,0.31$ & $0.26,0.42$ & 0.40 & 0.25 & 0.13 & 51.0 & \\
\hline & YK 130 & 2 & 0.57 & 0.29 & $0.18,0.34$ & 0.25 & 0.40 & 0.25 & 0.15 & & \\
\hline \multirow{7}{*}{$\begin{array}{l}\text { Rhodotorula } \\
\quad \text { minuta var. } \\
\text { texensis }\end{array}$} & YK 131 & 1 & 0.53 & 0.25 & $0.19,0.31$ & 0.29 & 0.43 & 0.25 & 0.14 & 50.2 & \multirow{7}{*}{10} \\
\hline & YK 132 & 1 & 0.53 & 0.25 & $0.17,0.31$ & 0.26 & 0.43 & 0.25 & 0.14 & 51.0 & \\
\hline & YK 133 & 1 & 0.53 & 0.25 & $0.19,0.31$ & 0.26 & 0.43 & 0.25 & 0.14 & & \\
\hline & YK 134 & 1 & 0.53 & 0.25 & $0.19,0.31$ & 0.29 & 0.43 & 0.24 & 0.14 & & \\
\hline & YK 135 & 3 & 0.49 & 0.29 & $0.18,0.36$ & 0.29 & 0.40 & 0.25 & 0.13 & & \\
\hline & YK 136 & 3 & 0.49 & 0.29 & $0.11,0.33$ & 0.26 & $0.48,0.50$ & 0.24 & 0.14 & & \\
\hline & YK 137 & 2 & 0.57 & 0.29 & $0.19,0.36$ & 0.26 & 0.43 & 0.24 & 0.15 & & \\
\hline
\end{tabular}

${ }^{a}$ From Nakase and Komagata (31).

${ }^{b}$ From Yamada and Kondo (52).

rula minuta var. minuta YK 129 and YK 130 and Rhodotorula minuta var. texensis YK 137 were included in this group. Members of group 3 produced FA with an $R_{m}$ of 0.49 and 6 PGDH with an $R_{m}$ of 0.29 ; Rhodotorula minuta var. texensis YK 135 and YK 136 were included in this group. Rhodotorula marina YK 136 and YK 137 were reidentified as Rhodotorula minuta var. texensis in this study. The one strain in group 4, strain YK 128, produced FA with an $R_{m}$ of 0.53 and $6 \mathrm{PGDH}$ with an $R_{m}$ of 0.30 .

Rhodotorula aurantiaca YK 100 and YK 101 were nearly identical with respect to their 6PGDH, MDH, HK, G6PDH, and GDH patterns, but the PGm patterns of these two strains differed (Table 5).

Of the three Rhodotorula lactosa strains tested, YK 122 and YK 123 showed identical patterns, but YK 124 differed from both of these strains in all enzymes (Table 5).

Of the three Rhodotorula graminis strains tested, YK 119 and YK 120 exhibited identical patterns in all enzymes, but YK 121 showed patterns different from the patterns of YK 119 and YK 120 (Table 5).

Of 16 Rhodotorula rubra strains, 14 exhibited patterns which were similar with respect to FA, 6PGDH, MDH, HK, and PGm but showed variations in G6PDH $\left(R_{m}, 0.31,0.33\right.$, or 0.35$)$ and GDH $\left(R_{m}, 0.13,0.15\right.$, or 0.16$)$ (Table 5). Of the other two strains, YK 155 produced characteristic patterns for 6PGDH $\left(R_{m}, 0.36,0.38\right.$, and $0.42)$ and G6PDH $\left(R_{m}, 0.24,0.26\right.$, and 0.30$)$ but produced the same patterns for the other enzymes as the other strains. YK 156 produced characteristic patterns for $6 \mathrm{PGDH}\left(R_{m}, 0.36\right.$, 0.39 , and 0.42$)$ and $\mathrm{MDH}\left(R_{m}, 0.29,0.32,0.34\right.$, $0.37,0.39$, and 0.42 ) but the same patterns for the other enzymes as the other strains.

Rhodotorula pilimanae strains produced the same patterns as Rhodotorula rubra strains for FA, 6PGDH $\left(R_{m}, 0.36\right), \mathrm{MDH}, \mathrm{HK}, \mathrm{PGm}$, G6PDH $\left(R_{m}, 0.31\right)$, and GDH $\left(R_{m}, 0.16\right)$ (Table $5)$.

Rhodotorula marina YK 125 produced peculiar FA, 6PGDH, and HK patterns and resembled Rhodotorula pallida YK 138 and YK 159 in its FA, 6PGDH, HK, and GDH patterns (Table 5).

Of the three Rhodotorula pallida strains tested, YK 138 and YK 159 showed identical patterns for all enzymes, but YK 160 was different from these two strains in all enzymes (Table $5)$.

Rhodotorula araucariae YK 161 and YK 162 differed from each other in their FA, 6PGDH, $\mathrm{HK}, \mathrm{PGm}$, and G6PDH patterns (Table 5).

Rhodotorula acheniorum YK 163 and YK 164 produced identical patterns for all enzymes (Table 5).

Rhodotorula sinensis YK 165 produced a characteristic pattern for FA and 6PGDH (Table 5).

Interrelationships between the genus Rhodotorula and the genus Rhodosporidium on the basis of the enzymatic patterns. Rhodotorula glutinis var. glutinis YK 102 and YK 103 (group 1) were similar to Rhodosporidium toruloides YK 218 and YK 219 (which were received as self-sporulating strains) with respect to FA, $6 \mathrm{PGDH}, \mathrm{MDH}$, and GDH.

Rhodotorula glutinis var. rufusa YK 117 produced a pattern identical to the patterns of the mating type strains of Rhodosporidium toruloides in their respective enzymes.

Rhodotorula glutinis var. salinaria YK 118 produced a pattern identical to the patterns of Rhodosporidium sphaerocarpum strains for all enzymes.

Rhodotorula glutinis var. glutinis YK 104 


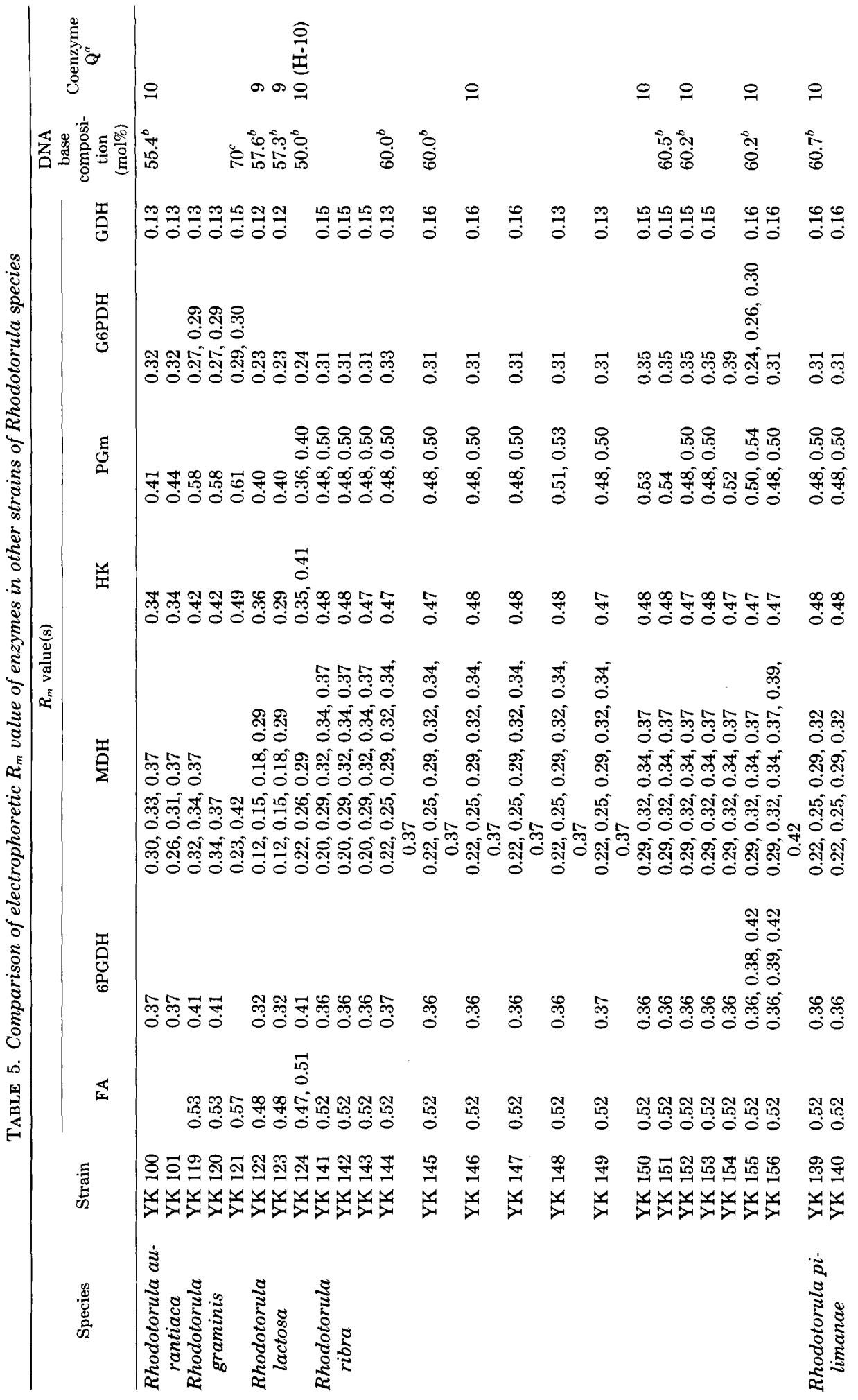




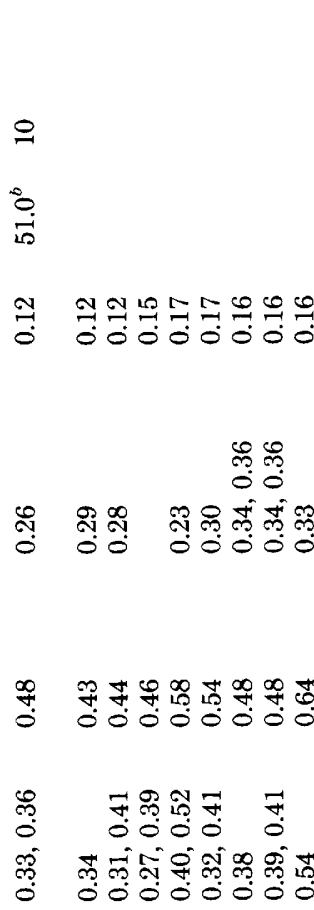

(Rhodotorula glutinis group 1) was similar to three strains of Rhodosporidium diobovatum (YK 223, YK 225, and YK 226) for all enzymes.

In Rhodotorula glutinis group 4, strains YK 108 and YK 111 were similar to Rhodosporidium bisporidiis strains with respect to FA, HK, PGm, and G6PDH but not with respect to 6PGDH and $\mathrm{MDH}$.

Rhodotorula graminis YK 121 resembled Rhodosporidium diobovatum strains with respect to FA, MDH, PGm, and GDH, but other Rhodotorula graminis strains did not.

Rhodotorula pallida YK 160 was similar to Rhodosporidium dacryoidum YK 235 with respect to FA, 6PGDH, MDH, and GDH, but other Rhodotorula pallida strains showed no similarity to any Rhodosporidium strain.

Rhodotorula araucariae YK 162 was similar to all Rhodosporidium dacryoidum strains except YK 235 with respect to $6 \mathrm{PGDH}, \mathrm{MDH}$, and HK.

Rhodotorula sinensis YK 165 was similar to Rhodosporidium infirmo-miniatum YK 240 with respect to $6 \mathrm{PGDH}, \mathrm{MDH}, \mathrm{HK}, \mathrm{G} 6 \mathrm{PDH}$, and GDH, to YK 241 and YK 242 with respect to 6PGDH, MDH, PGm, G6PDH, and GDH, and to YK 243 with respect to FA, MDH, HK, and GDH.

A total of 16 Rhodotorula rubra strains, 2 Rhodotorula pilimanae strains, 1 Rhodotorula marina strain, 5 Rhodotorula minuta var. minuta strains, 7 Rhodotorula minuta var. texensis strains, 3 Rhodotorula lactosa strains, and 2 Rhodotorula aurantiaca strains were not similar to any of the known strains of the genus Rhodosporidium.

Conjugation tests between strains showing similar enzymatic patterns. Compatible mating strains of each Rhodosporidium species had identical enzymatic patterns. Based on this observation, we expected that Rhodotorula strains would be able to conjugate with Rhodosporidium strains having similar patterns. Therefore, we performed conjugation tests between such strains.

The strains used were inoculated onto yeast extract-malt extract agar slants and incubated for 2 days at $25^{\circ} \mathrm{C}$. Two loopfuls of cells (one loopful of each of two strains) were mixed together and inoculated at the center of a corn meal agar plate. Cells of the two strains were also inoculated separately at other points on the same agar plate. The plate was incubated at $20^{\circ} \mathrm{C}$, and the growth of the mixed cells was observed with the naked eye and microscopically at intervals.

Table 6 shows the combinations of strains tested and the results obtained. Conjugation be- 
tween cells, mycelial development with clamp connections, and teliospore formation were observed with the following combinations: Rho-

TABLE 6. Results of the cell conjugation test which was suggested by the electrophoretic comparison of enzymes

\begin{tabular}{|c|c|c|c|}
\hline \multicolumn{2}{|c|}{ Anamorph } & \multicolumn{2}{|c|}{ Teleomorph } \\
\hline Species or variety & Strain & Species & $\begin{array}{l}\text { Mating } \\
\text { type }\end{array}$ \\
\hline $\begin{array}{l}\text { Rhodotorula glu- } \\
\text { tinis var. glu- } \\
\text { tinis }\end{array}$ & YK 104 & $\begin{array}{l}\text { Rhodosporidium } \\
\text { diobovatum }\end{array}$ & $\alpha$ \\
\hline $\begin{array}{l}\text { Rhodotorula glu- } \\
\quad \text { tinis var. ru- } \\
\text { fusa }\end{array}$ & YK 117 & $\begin{array}{l}\text { Rhodosporidium } \\
\text { toruloides }\end{array}$ & a \\
\hline $\begin{array}{l}\text { Rhodotorula glu- } \\
\text { tinis var. sali- } \\
\text { naria }\end{array}$ & YK 118 & $\begin{array}{l}\text { Rhodosporidium } \\
\text { sphaerocar- } \\
\text { pum }\end{array}$ & $\mathbf{a}$ \\
\hline $\begin{array}{l}\text { Rhodotorula si- } \\
\quad \text { nensis }\end{array}$ & YK 165 & $\begin{array}{l}\text { Rhodosporidium } \\
\text { infirmo-minia- } \\
\text { tum }\end{array}$ & $?$ \\
\hline
\end{tabular}

dotorula glutinis var. rufusa YK 117 and Rhodosporidium toruloides YK 201 (mating type A); Rhodotorula glutinis var. salinaria YK 118 and Rhodosporidium sphaerocarpum YK 221 (mating type $\alpha$ ); and Rhodotorula glutinis var. glutinis YK 104 and Rhodosporidium diobovatum YK 223 (mating type a) (Fig. 3 through 5).

These results clearly indicated that Rhodotorula glutinis var. rufusa YK 117 is the haploid mating type a of Rhodosporidium toruloides, Rhodotorula glutinis var. salinaria YK 118 is the haploid mating type a of Rhodosporidium sphaerocarpum, and Rhodotorula glutinis var. glutinis YK 104 is the haploid mating type $\alpha$ of Rhodosporidium diobovatum.

In the combination of Rhodotorula sinensis YK 165 and Rhodosporidium infirmo-miniatum, when strains YK 165 and YK 242 (mating type A2) were mixed, mycelial development and resting spores were observed, but conjugation and clamp connections were not (Fig. 6).

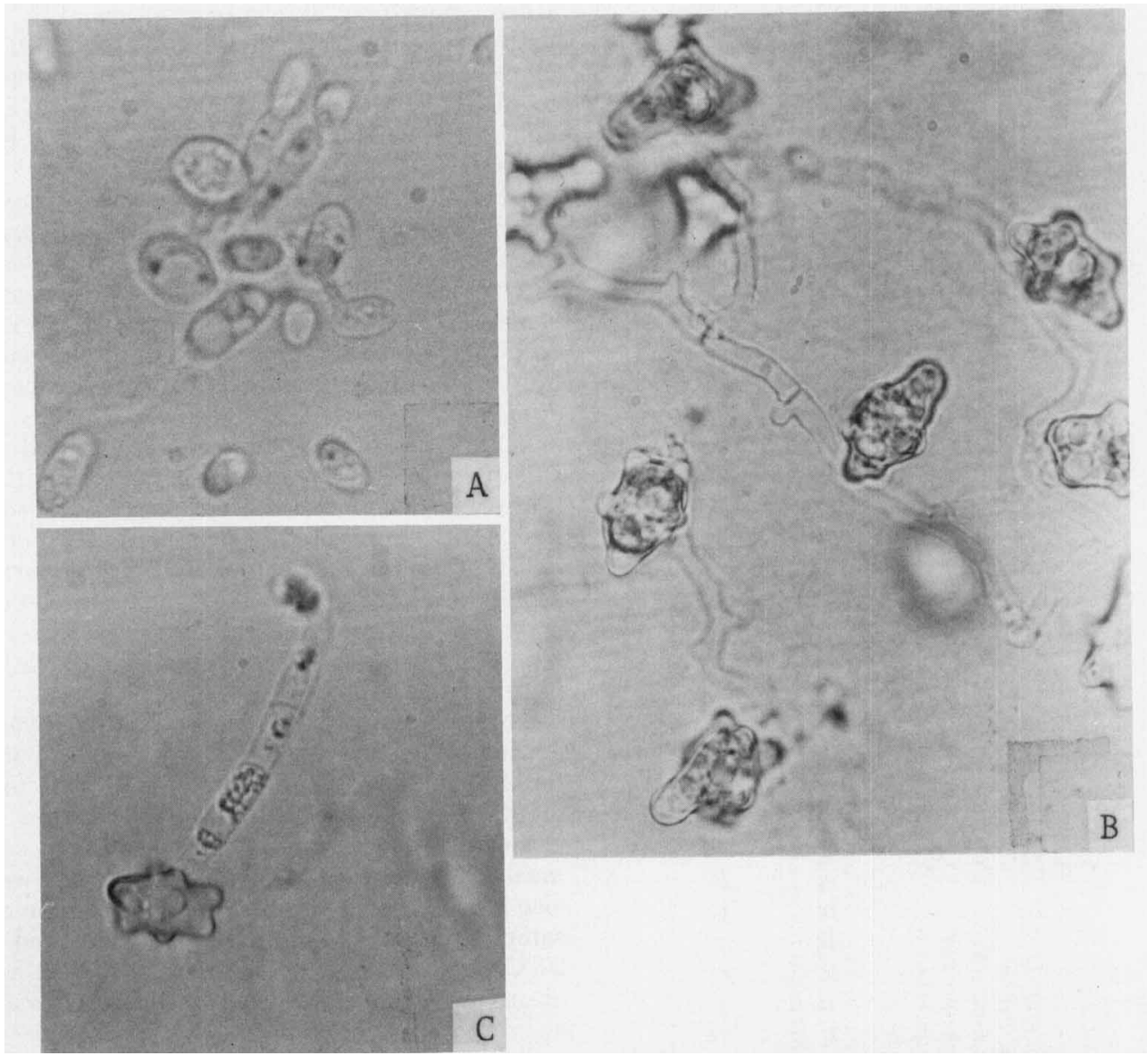

FIG. 3. Conjugation between Rhodotorula glutinis var. rufusa YK 117 and Rhodosporidium toruloides YK 201 (mating type A). (A) Conjugated cells, showing a copulation tube. (B) Teliospores and hyphae, showing a clamp connection. (C) Germinated teliospore. 


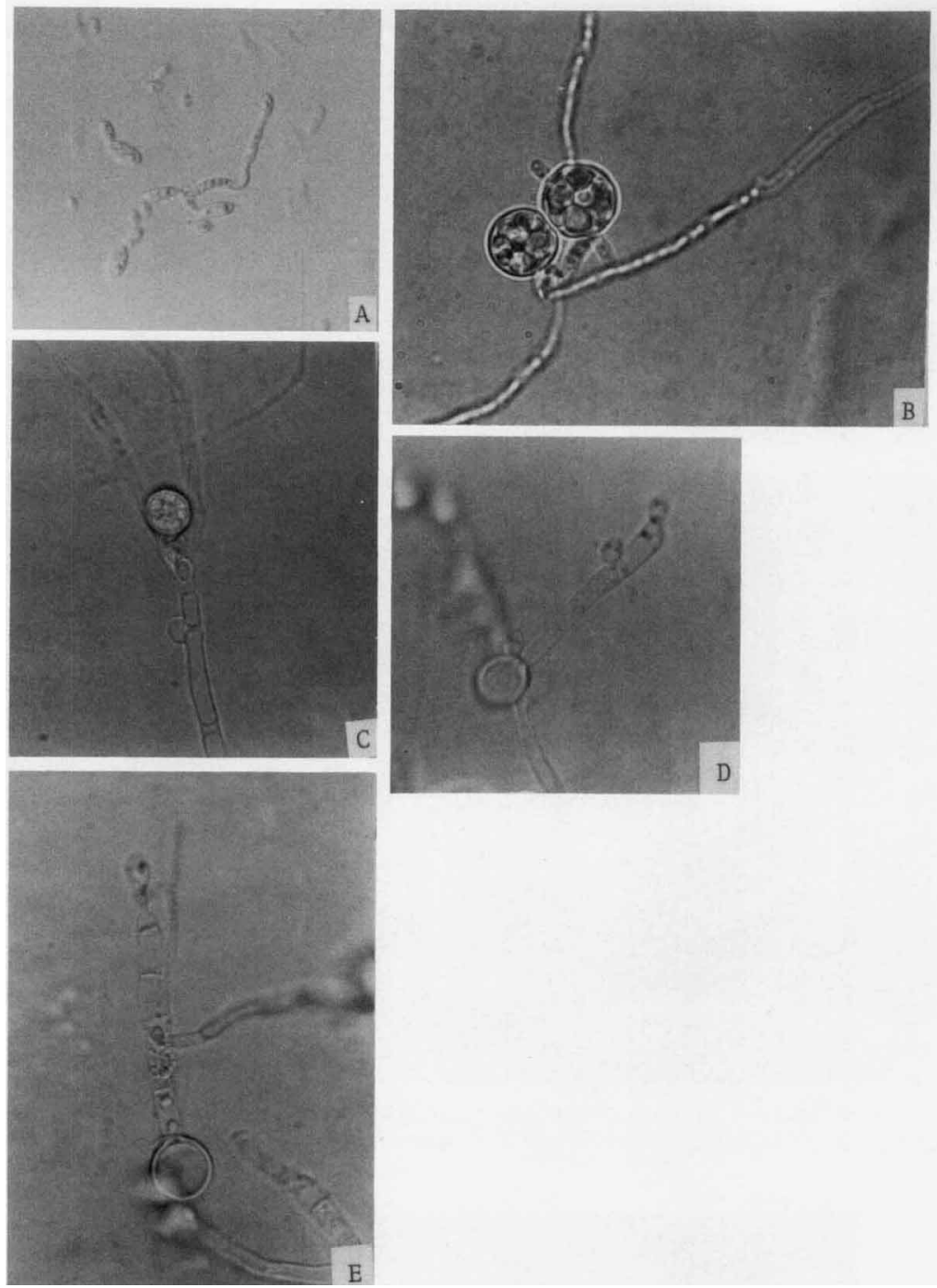

FIG. 4. Conjugation between Rhodotorula glutinis var. salinaria YK 118 and Rhodosporidium sphaerocarpum YK 221 (mating type a). (A) Hyphal development after conjugation. (B) and (C) Teliospores and hyphae, showing a clamp connection. (D) and (E) Germinated teliospore, showing promycelium and sporidia.

\section{DISCUSSION}

As discussed above, the electrophoretic patterns of enzymes are considered to be useful in the taxonomy of the genera Rhodosporidium and Rhodotorula.

Rhodosporidium. Almost all Rhodosporidium toruloides strains, irrespective of the mating type, produced identical electrophoretic patterns for the enzymes tested. However, we did find a few exceptional strains. For example, strains YK 214, YK 215, and YK 216 each conjugated with YK 201, YK 207, YK 208, YK 209, and YK 210 , but the $R_{m}$ values of six enzymes (but not 6PGDH) differed to some extent. It is not clear why strains with different patterns conjugated. Further genetic and biochemical investigations will be required to answer this question. Moreover, of three self-sporulating strains, YK 217 showed the same pattern as typical haploid mating type strains, and YK 218 and YK 219 differed from YK 217 in the shape of the teliospores. Strains YK 218 and YK 219 would be included in Rhodosporidium sphaerocarpum on the basis of the shapes of their teliospores (Fig. 7), but they would be excluded from this species on the basis of the differences in their enzymatic patterns (Table 2).

Keller and Wegener (26) reported that cell conjugation and teliospore formation were ob- 

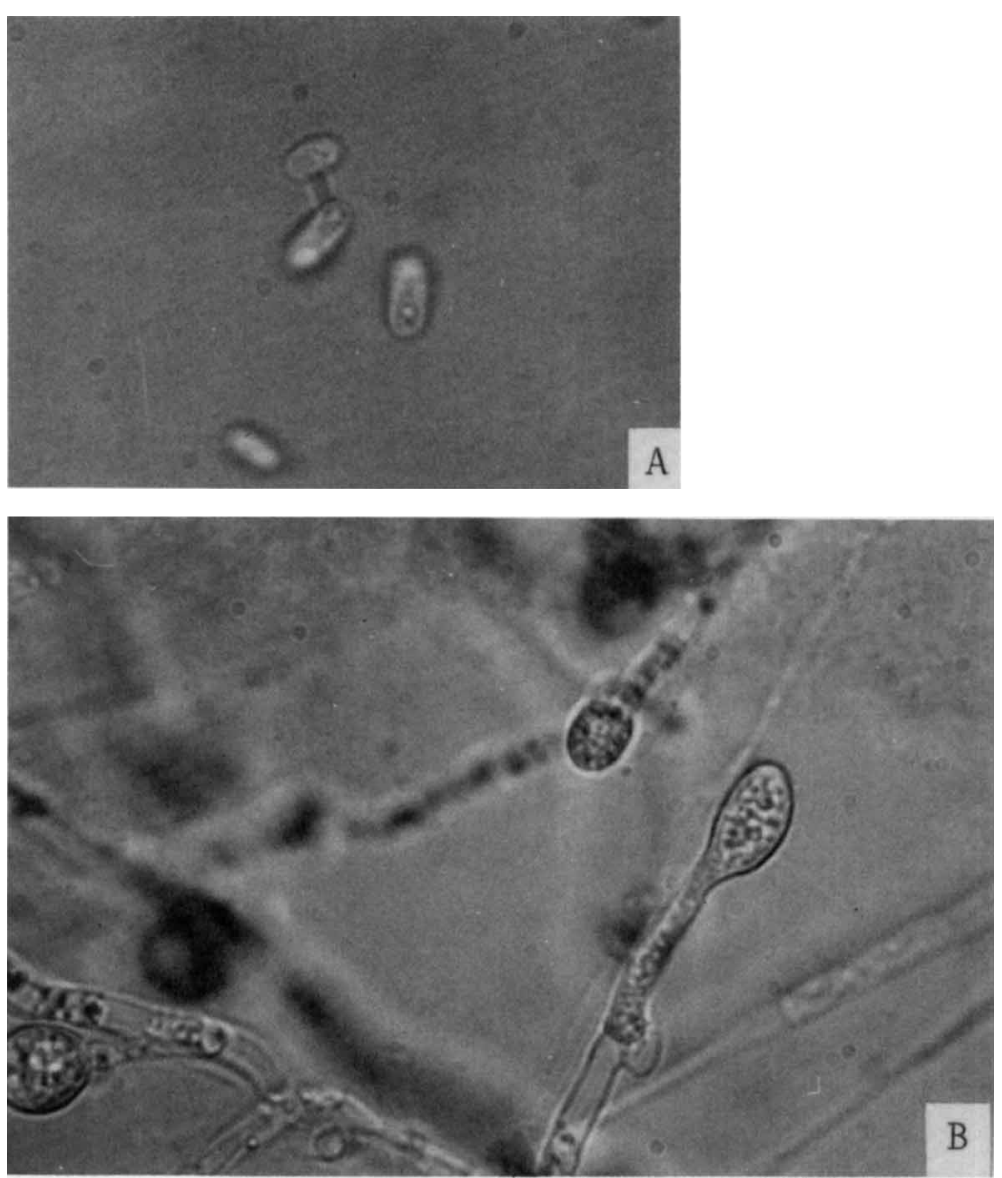

FIG. 5. Conjugation between Rhodotorula glutinis var. glutinis YK 104 and Rhodosporidium diobovatum YK 223 (mating type a). (A) Conjugated cells. (B) Teliospores and hyphae, showing a clamp connection.

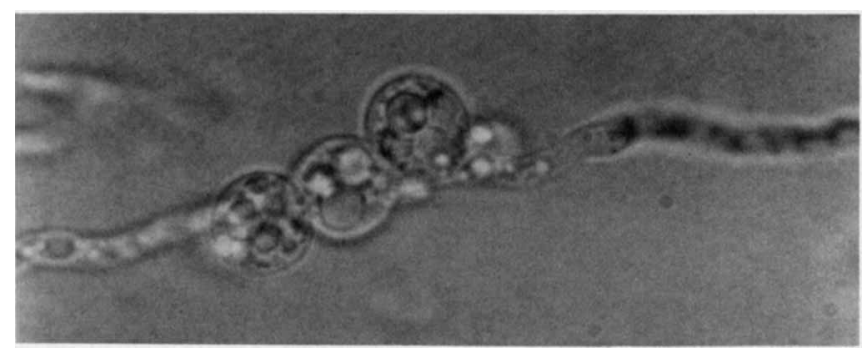

FIG. 6. Resting spores of Rhodotorula sinensis YK 165 mixed with Rhodosporidium infirmo-miniatum YK 242 (mating type A2).

served in matings between Rhodotorula glutinis and Rhodotorula rubra. Strains YK 207, YK 208, YK 209, and YK 210 were received as haploid strains of mating type A of Rhodosporidium toruloides. It has been reported that these strains do not assimilate potassium nitrate. Therefore, it is reasonable that these strains were identified as Rhodotorula rubra according to the conventional identification methods, using only physiological and morphological features. When they were mixed with Rhodosporidium toruloides YK 211 cells of haploid mating type a, conjugation, mycelial development with clamp connections, and teliospore formation were observed. These results confirmed those of Keller and Wegener (26). The strains 

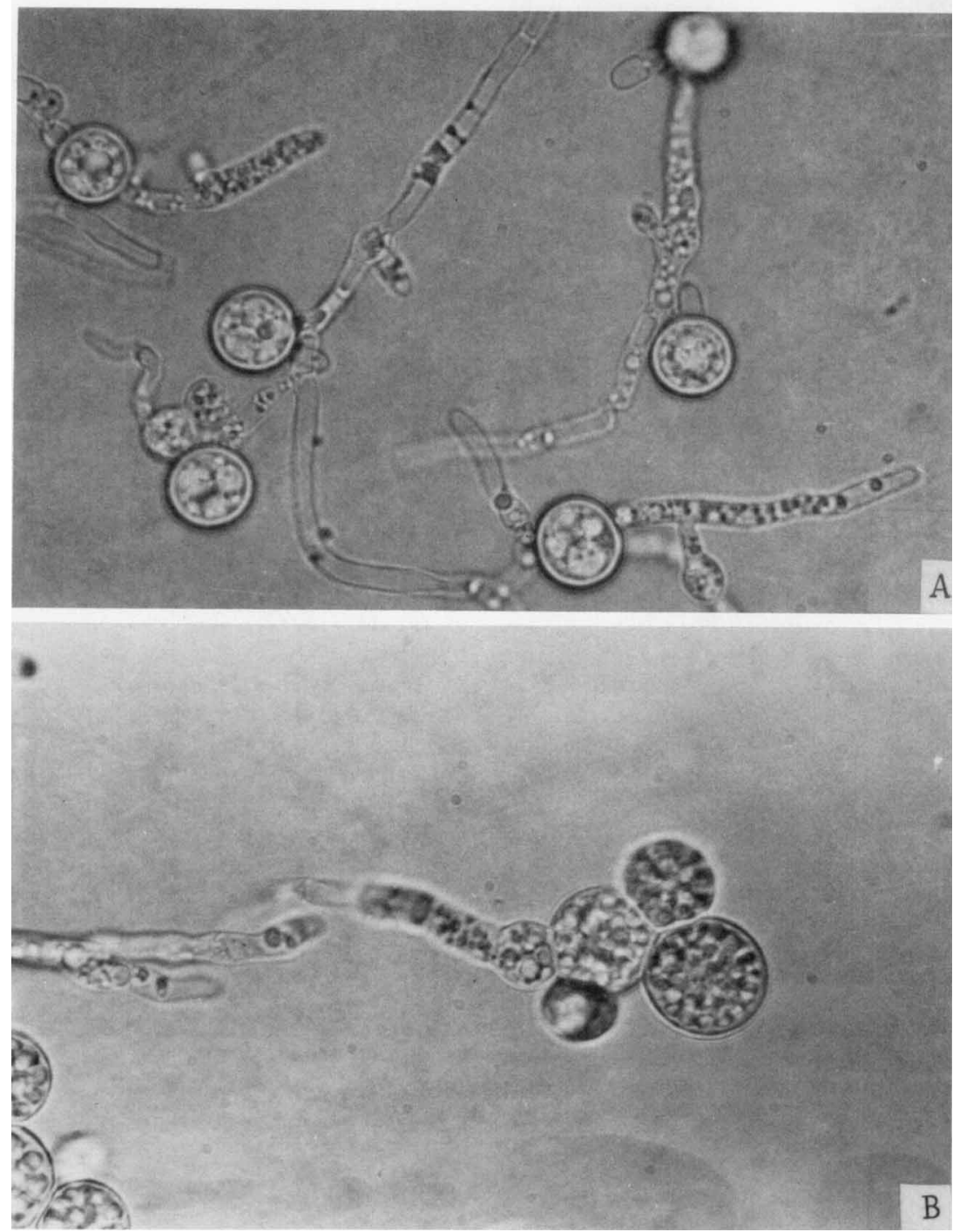

FIG. 7. Teliospores of two self-sporulating strains. (A) Rhodosporidium toruloides YK 218. (B) Rhodosporidium sphaerocarpum YK 222.

received as $R$ hodotorula rubra showed the same enzymatic pattern as Rhodosporidium toruloides. From these results, we concluded that these strains had lost the ability to assimilate potassium nitrate. In the anamorph, strains of Rhodosporidium toruloides, Rhodosporidium sphaerocarpum, and Rhodosporidium diobovatum that do not assimilate nitrate might be included in Rhodotorula rubra. We believe that these findings make the identification of such strains troublesome by the criteria commonly used, and comparing the electrophoretic patterns of the enzymes is a useful solution.

The DNA base composition (32) and coenzyme $Q$ system (52) of Rhodosporidium malvi- nellum were reported to be the same as those of Rhodotorula minuta and Rhodotorula pallida. However, Rhodosporidium malvinellum strains produced an enzyme pattern similar to the patterns Rhodotorula minuta and Rhodotorula pallida only with respect to HK. Therefore, we believe that the Rhodotorula minuta and Rhodotorula pallida strains examined in this study are not the anamorph of Rhodosporidium malvinellum.

Of the four Rhodosporidium diobovatum strains tested, YK 224 differed from the other three strains in its zymogram and rather resembled Rhodosporidium bisporidiis. It did not mate with the mating type strains of either 
species. Therefore, further investigations will be required for a better understanding of this strain from a biochemical standpoint.

Of the five Rhodosporidium dacryoidum strains examined, the self-sporulating strain YK 235 produced a pattern similar to that of $R h o$ dotorula pallida YK 160. Strain YK 235 was isolated from a cross between Rhodosporidium dacryoidum YK 231 and YK 232 and is believed to be a mutant similar to the Amut Bx heterokaryon mimics of Coprinus lagopus and Schizophyllum commune (11). Other information will be necessary to reveal the correct taxonomic position of this strain.

Rhodosporidium infirmo-miniatum is a peculiar species which possesses coenzyme $Q_{8}(52)$ and is bipolar with three known alleles (11). The anamorph of this species has been classified in the genus Cryptococcus because of its assimilation of inositol. Conjugation between strain YK 243 and other Rhodosporidium infirmo-miniatum strains was not observed. We could not determine whether strain YK 243 belongs to Rhodosporidium infirmo-miniatum.

Rhodosporidium capitatum is a self-sporulating species which has a life cycle similar to that described for a self-sporulating strain of Rhodosporidium sphaerocarpum (11), but the enzymatic patterns of these two strains were not similar.

All of the Rhodosporidium species produced different enzymatic patterns. Nakase and Ko- magata (32) reported that in the genus Rhodosporidium the $\mathrm{G}+\mathrm{C}$ contents of the DNAs ranged from 50.5 to $67.3 \mathrm{~mol} \%$, and Yamada and Kondo (52) reported that the coenzyme $Q$ systems of these species were $Q_{8}, Q_{9}$, or $Q_{10}$. Based on these results and those reported by other workers, this genus will have to be divided into several taxa in the near future.

Rhodotorula. Hasegawa et al. $(21,22)$ divided the genus Rhodotorula into two subgenera, Rubrotorula and Flavotorula, mainly on the basis of the absorption spectra of pigments. These authors further divided the subgenus Rubrotorula into three groups on the basis of cell morphology, requirements for vitamins, and assimilation of lactose. Nakase and Komagata (31) determined the $\mathrm{G}+\mathrm{C}$ contents of the DNAs and reported four groups in this genus. Yamada and Kondo (52) determined the coenzyme $Q$ systems and reported the presence of $Q_{8}, Q_{9}$, or $Q_{10}$. Table 7 shows the results obtained by these workers.

Strains of Rhodotorula glutinis and its varieties were divided into six groups on the basis of FA and 6PGDH patterns because these two enzymes showed specific patterns within the species of Rhodotorula and Rhodosporidium and other enzymes did not. Rhodotorula glutinis was considered to be heterogenous with respect to enzymatic pattern. Rhodotorula glutinis var. glutinis strains YK 102 and YK 103, with $\mathrm{G}+\mathrm{C}$ contents of $67 \mathrm{~mol} \%$, were similar to

TABLE 7. Grouping of Rhodotorula species ${ }^{a}$

\begin{tabular}{|c|c|c|c|c|c|c|}
\hline Group & Species & $\begin{array}{l}\text { DNA base } \\
\text { composition } \\
\text { (mol\%) }\end{array}$ & Coenzyme Q & $\begin{array}{l}\text { Require- } \\
\text { ment for } \\
\text { biotin }\end{array}$ & $\begin{array}{l}\text { Require- } \\
\text { ment for } p \text { - } \\
\text { aminoben- } \\
\text { zoic acid }\end{array}$ & $\begin{array}{c}\text { Grouping } \\
\text { by Hase- } \\
\text { gawa }\end{array}$ \\
\hline \multirow[t]{4}{*}{1} & Rhodotorula infirmo-miniata & $67.8-68.5$ & 8 & + & - & III \\
\hline & Rhodotorula glutinis & $66.8-67.8$ & 10 & - & - & I \\
\hline & Rhodotorula glutinis & $60.2-61.2$ & 9 or 10 & - & - & I \\
\hline & $\begin{array}{l}\text { Rhodotorula glutinis var. } \\
\text { dairenensis }\end{array}$ & 61.2 & 10 & - & - & $\mathbf{I}$ \\
\hline \multirow[t]{4}{*}{2} & $\begin{array}{l}\text { Rhodotorula glutinis var. ru- } \\
\text { fusa }\end{array}$ & 60.0 & 9 & - & - & I \\
\hline & Rhodotorula rubra & $60.0-61.2$ & 10 & - & - & I \\
\hline & Rhodotorula pilimanae & 60.7 & 10 & - & - & I \\
\hline & $\begin{array}{l}\text { Rhodotorula glutinis var. au- } \\
\quad \text { rantiaca }\end{array}$ & 55.4 & 10 & - & - & I \\
\hline \multirow[t]{5}{*}{3} & Rhodotorula crocea & 58.8 & 10 & - & - & II \\
\hline & Rhodotorula lactosa & $57.3-57.6$ & 9 & - & + & II \\
\hline & Rhodotorula lactosa & 50.0 & $10(10-10)$ & - & + & II \\
\hline & Rhodotorula pallida & 51.0 & 10 & - & + & II \\
\hline & Rhodotorula marina & 51.0 & 10 & - & + & II \\
\hline \multirow[t]{4}{*}{4} & Rhodotorula minuta & 51.0 & 10 & - & + & II \\
\hline & Rhodotorula zsoltii & 51.0 & 10 & - & + & II \\
\hline & Rhodotorula slooffii & 50.7 & 10 & - & + & II \\
\hline & Rhodotorula texensis & $50.2-50.7$ & 10 & - & + & II \\
\hline
\end{tabular}
(52). 
Rhodosporidium toruloides YK 218 and YK 219, which differ from the other Rhodosporidium toruloides strains in their enzymatic patterns. Hyphae were not observed with YK 102 and YK 103 on corn meal agar. Rhodotorula glutinis var. glutinis YK 104 (group 1) was once identified as Rhodotorula glutinis var. lusitanica by Marcilla et al. (29) and was then transferred to Rhodotorula glutinis var. glutinis by Phaff and Ahearn (37). This strain was the haploid mating type $\alpha$ of Rhodosporidium diobovatum according to the results of a conjugation test which was performed because of the similarities found in the enzymatic patterns. YK 114 and YK 115 (group 2) were isolated from core samples from stratigraphic drillings in Japan and were described by Sugiyama and Goto (45). These strains and Rhodotorula glutinis var. dairenensis YK 116 produced similar patterns. YK 116 differs from other Rhodotorula glutinis var. glutinis strains by its weak assimilation of potassium nitrate. However, strains YK 114, YK 115 , and YK 116 are considered to be closely related on the basis of their enzymatic patterns. YK 112 and YK 113 (group 3) were isolated from Himalayan soil (15), and these strains were quite different from other Rhodotorula and Rhodosporidium strains in their enzymatic patterns. Therefore, they are considered to be anamorphs of an as-yet-undescribed species of Rhodosporidium or another genus. Of 14 Rhodotorula glutinis var. glutinis strains, 7 were included in group 4. YK 110 was received as Rhodotorula graminis, but this strain assimilated melezitose strongly and therefore was transferred to Rhodotorula glutinis var. glutinis in this study. This decision was supported by the results of the enzymatic pattern determinations. Strains with different $\mathrm{G}+\mathrm{C}$ contents in their DNAs were included in this group (that is, YK 105 [61.2 mol\%] and YK 108 [66.8 $\mathrm{mol} \%]$ ). These strains were dissimilar in their $\mathrm{MDH}$ and PGm patterns. Consequently, we believe that this group contains phylogenetically different strains, and further investigations will be required for this group in still other respects.

Rhodotorula glutinis var. rufusa YK 117 was isolated from the water (depth, $15 \mathrm{~m}$ ) of Lake Vanda in Antarctica and was identified by Goto et al. (16). This strain was found to be the haploid mating type a of Rhodosporidium toruloides by the conjugation test which was performed as a result of the similarity found after a comparison of the enzymes. Yamada and Kondo (52) reported that a strain of Rhodotorula glutinis var. rufusa (IFO 1638, RJ-5) was the haploid mating type a of Rhodosporidium toruloides on the basis of its coenzyme Q system and a conjugation test. Rhodosporidium toruloides strains have not been found yet in Antarctica; therefore, YK 117 is considered to be interesting from an ecological point of view.

Rhodotorula glutinis var. salinaria YK 118 was isolated as a halophilic yeast from a salt farm at Yashima along the shore of Seto Inland Sea in Japan and was described by Hirosawa and Takada (23). This strain was found to be the haploid mating type a of Rhodosporidium sphaerocarpum by the conjugation test which was suggested by an electrophoretic comparison of enzymes. An anamorph strain of Rhodosporidium sphaerocarpum has not been found among the strains which have been preserved in culture collections up to this time. Therefore, this strain is also considered to be of interest from an ecological viewpoint.

Nakase and Komagata (31) divided Rhodotorula glutinis var. glutinis strains into two groups on the basis of the $\mathrm{G}+\mathrm{C}$ contents of their DNAs (60 and $67 \mathrm{~mol} \%)$. The strains of group 2 (60 mol\%) were assigned to Rhodosporidium toruloides. Yamada and Kondo (52) further divided this group into two subgroups on the basis of coenzyme $Q$ systems. The first subgroup possessed $Q_{10}$, whereas the second, which included the haploid mating strains of Rhodosporidium toruloides, had Q9. Nakase and Komagata (32) mentioned that group 1 ( $67 \mathrm{~mol} \%)$ might be the anamorph of Rhodosporidium diobovatum because the DNAs of these strains have the same $\mathrm{G}+\mathrm{C}$ contents (about $67 \mathrm{~mol} \%$ ) and that another teleomorph might be found among the strains of group 2 which showed the presence of $Q_{10}$ and 60.7 to $61.2 \mathrm{~mol} \% \mathrm{G}+\mathrm{C}$. Strains YK 102, YK 103, and YK 108 possessed 66.8 to $67.3 \mathrm{~mol} \% \mathrm{G}+\mathrm{C}$ (31), but the enzymatic patterns of these strains were different from those of Rhodosporidium diobovatum strains. Therefore, a new teleomorph might be expected for these strains. The teleomorph of YK 106, which has $Q_{10}$ and 61.2 $\mathrm{mol} \% \mathrm{G}+\mathrm{C}$, was not found in this study.

The haploid mating type strains of three Rhodosporidium species were found among the strains of Rhodotorula glutinis and its varieties as the result of conjugation tests which were suggested by electrophoretic comparisons of enzymes. Furthermore, new teleomorphs were suggested by the results of the enzymatic pattern determinations.

According to Phaff and Ahearn (37), Rhodotorula minuta var. texensis differs from Rhodotorula minuta var. minuta by the strong assimilation of lactose, but these varieties are very similar in all other respects. All strains of both varieties produced unique $6 \mathrm{PGDH}\left(R_{m}, 0.25\right.$ or $0.29)$ and HK $\left(R_{m}, 0.26\right.$ or 0.29$)$ patterns, which 
were not detected in other Rhodotorula species. Rhodotorula minuta var. minuta YK 126 and Rhodotorula minuta var. texensis YK 131 are the type strains of their varieties, and these two strains have the same coenzyme $Q$ system, identical enzyme patterns, and similar $\mathrm{G}+\mathrm{C}$ contents of their DNAs. From these results, we believe that differentiation between Rhodotorula min. uta var. minuta and Rhodotorula minuta var. texensis on the basis of assimilation of lactose alone is not sound. These two varieties should be joined because of their enzymatic patterns and the above-mentioned considerations.

Rhodotorula aurantiaca was once described as a variety of Rhodotorula glutinis (21), but it was elevated to species status by Phaff and Ahearn (37) on the basis of its physiological properties. Tsuchiya et al. (46) reported that Rhodotorula glutinis and Rhodotorula aurantiaca possess the same antigenic structures, but Nakase and Komagata (31) pointed out that Rhodotorula aurantiaca was considered to be a species distinct from Rhodotorula glutinis because a difference of more than $5 \mathrm{~mol} \%$ in the DNA base compositions of the two species was found. Furthermore, Rhodotorula aurantiaca differs from Rhodotorula glutinis with respect to enzymatic patterns. Therefore, we believe that Rhodotorula aurantiaca should be a species distinct from Rhodotorula glutinis.

Rhodotorula graminis YK 119 and YK 120 were once identified as Rhodotorula rosa by Goto and Yokotsuka (18) and as Sporobolomyces coprophilus by Sugiyama and Goto (44); later, these two strains were identified as Rhodotorula graminis by Phaff and Ahearn (37). The enzymatic patterns of these strains are identical. On this basis, the identification of these strains by Phaff and Ahearn was confirmed. The enzymatic pattern of YK 121, which is the type strain of Rhodotorula graminis, was not similar to the patterns of YK 119 and YK 120 but was similar to the patterns of Rhodosporidium diobovatum strains. Fell (10) stated that Rhodotorula graminis may consist of two distinct species, namely, Rhodosporidium malvinellum and Sporidiobolus ruinenii. Moreover, all three of these taxa grew on the same carbon compounds, but the color of the type strain of Rhodotorula graminis was different from that of Rhodosporidium malvinellum. Rhodotorula graminis and Rhodosporidium diobovatum strains did not mate. Nakase and Komagata (32) pointed out that the G+C content of the DNA of Rhodosporidium malvinellum was $50.0 \mathrm{~mol} \%$ and thus was about $20 \mathrm{~mol} \%$ lower than that of the type strain of Rhodotorula graminis, as reported by Storck et al. (43). The enzymatic pattern of the type strain of Rhodotorula graminis differed from the patterns of Rhodosporidium malvinellum strains. We believe that Rhodotorula graminis strains have phylogenetic relationships to Rhodotorula glutinis and Rhodosporidium diobovatum on the basis of the $\mathrm{G}+\mathrm{C}$ contents of their DNAs and their enzymatic patterns.

Rhodotorula lactosa appeared to be an interesting species in the genus Rhodotorula, and the strains of this species were divided into two groups on the basis of the $\mathrm{G}+\mathrm{C}$ contents of their DNAs (31) and their coenzyme Q systems (52). Rhodotorula lactosa YK 124 originated from Rhodotorula aurantiaca ATCC 9536, which was identified as Rhodotorula lactosa by Hasegawa (20), but its pattern of assimilation of carbon compounds was not similar to the patterns of Rhodotorula lactosa YK 122 and YK 123 (Table 8). In addition, Yamada et al. $(50,52)$ found that the assimilation patterns of these strains were not similar, with the exception of the assimilation of potassium nitrate and maltose. The assimilation pattern of Rhodotorula lactosa YK 124 was similar to that of Rhodotorula aurantiaca YK 100, but the DNA base compositions of those two strains were dissimilar. With respect to enzymatic patterns, $R h o$ dotorula lactosa YK 124 was not similar to other Rhodotorula lactosa strains. Consequently, we believe that YK 124 may be a new species in the genus Rhodotorula or an anamorph of an unknown teleomorphic species.

Of four Rhodotorula marina strains, YK 136 and YK 137 were identified as Rhodotorula minuta var. texensis, although they assimilated lactose strongly but not raffinose. Strain YK 154 was identified as Rhodotorula rubra because of the strong assimilation of maltose. According to Phaff and Ahearn (37), Rhodotorula marina is a physiologically unstable species. The enzymatic patterns of strains YK 136, YK 137, and YK 154 indicated similarities to strains of $R$ hodotorula minuta and Rhodotorula rubra. The remaining Rhodotorula marina strain, YK 125, is the type strain, and its enzymatic pattern was different from the patterns of all of the other Rhodotorula species except Rhodotorula pallida.

Of three Rhodotorula pallida strains, YK 160 showed a pattern similar to that of Rhodosporidium dacryoidum YK 235 but did not mate with the mating types of this species. Fell et al. (11) reported that Rhodosporidium dacryoidum showed the same assimilation pattern as Rhodotorula minuta and Rhodotorula pallida but that it did not mate with the type strain of either species. The $\mathrm{G}+\mathrm{C}$ contents of the DNAs, the coenzyme $Q$ systems, and the requirements for vitamins are similar in Rhodotorula minuta and Rhodotorula pallida, but with the exception of 
TABLE 8. Some physiological and biochemical properties of Rhodotorula lactosa and Rhodotorula aurantiaca strains

\begin{tabular}{|c|c|c|c|c|c|c|c|c|c|c|}
\hline \multirow[b]{2}{*}{ Species } & \multirow[b]{2}{*}{ Strain } & \multicolumn{7}{|c|}{ Assimilation of: } & \multirow{2}{*}{$\begin{array}{c}\text { DNA } \\
\text { base } \\
\text { composi- } \\
\text { tion } \\
\text { (mol\%) }\end{array}$} & \multirow[b]{2}{*}{$\begin{array}{l}\text { Coenzyme } \\
Q^{c}\end{array}$} \\
\hline & & Sucrose & Maltose & Lactose & $\begin{array}{l}\text { Melibi- } \\
\text { ose }\end{array}$ & $\begin{array}{l}\text { Raffi- } \\
\text { nose }\end{array}$ & $\begin{array}{l}\text { Melezi- } \\
\text { tose }\end{array}$ & $\mathrm{NO}_{3}{ }^{a}$ & & \\
\hline $\begin{array}{l}\text { Rhodotorula lac- } \\
\quad \text { tosa }\end{array}$ & YK 124 & + & + & - & - & - & + & + & 50.0 & $10(\mathrm{H}-10)$ \\
\hline $\begin{array}{l}\text { Rhodotorula lac- } \\
\text { tosa }\end{array}$ & $\mathrm{R} 1^{c}$ & + & - & - & - & - & + & - & 50.0 & $10(\mathrm{H}-10)$ \\
\hline $\begin{array}{l}\text { Rhodotorula lac- } \\
\quad \text { tosa }\end{array}$ & YK 122 & + & + & + & + & + & + & + & 57.3 & 9 \\
\hline $\begin{array}{l}\text { Rhodotorula lac- } \\
\quad \text { tosa }\end{array}$ & YK 123 & + & + & + & + & + & + & + & 57.6 & 9 \\
\hline $\begin{array}{l}\text { Rhodotorula au- } \\
\text { rantiaca }\end{array}$ & YK 100 & + & + & - & - & - & + & + & 55.4 & 10 \\
\hline
\end{tabular}

\footnotetext{
${ }^{a}$ Potassium nitrate.

${ }^{b}$ From Nakase and Komagata (31).

${ }^{c}$ From Yamada et al. $(50,52)$.
}

YK 160, neither species had an enzyme pattern similar to that of Rhodosporidium dacryoidum. Storck et al. (43) reported that the $\mathrm{G}+\mathrm{C}$ contents of the DNAs of two strains of Rhodotorula pallida were 54.5 and $63.5 \mathrm{~mol} \%$. Thus, Rhodotorula pallida is a heterogenous species and includes strains related to Rhodosporidium dacryoidum.

Rhodotorula rubra, a species commonly found in nature, includes morphologically different strains which were once recognized as separate species. Strains YK 142, YK 146, YK 150, YK 151, and YK 152 were once named Rhodotorula mucilaginosa, but they were combined with Rhodotorula rubra by Hasegawa (20) because of instability of their cell shapes. Rhodotorula rubra strains and the strains once named Rhodotorula mucilaginosa showed similar enzymatic patterns and could not be separated from each other. Strain YK 154 was received as Rhodotorula marina but was identified as Rhodotorula rubra in this study because of its strong assimilation of maltose. This strain had an enzyme pattern similar to that of other Rhodotorula rubra strains for six enzymes but not for G6PDH. Strains YK 155 and YK 156 had three 6 PGDH bands. On this basis, these strains might be separated from Rhodotorula rubra. Rhodotorula rubra differs from Rhodotorula glutinis by not assimilating potassium nitrate, but the carbon assimilation spectra of the these two species are nearly identical. Rhodotorula glutinis and Rhodotorula rubra showed clear differences in the electrophoretic patterns of their enzymes. Therefore, comparisons of the electrophoretic patterns of enzymes are useful for differentiating these two species.

Rhodotorula pilimanae differs from Rhodo- torula rubra by not assimilating maltose and melezitose, but these two species have identical $\mathrm{G}+\mathrm{C}$ contents in their DNAs (31) and identical coenzyme $Q$ systems (52). Rhodotorula pili. manae could not be differentiated from Rhodotorula rubra on the basis of enzymatic patterns. Phaff and Ahearn (37) point out that Rhodotorula pilimanae resembles Rhodotorula minuta in its physiological properties. However, there was no resemblance between these two species in their enzymatic patterns and the $\mathrm{G}+\mathrm{C}$ contents of their DNAs (31). As the electrophoretic mobilities of enzymes reflect even slight variations in enzyme structures, we believe that $R h o-$ dotorula pilimanae should be included in Rhodotorula rubra.

Rhodotorula araucariae, which was isolated from a rotting Araucaria araucana tree in Llaima, Chile, was described by Grinbergs and Yarrow (19). This species closely resembles Rhodotorula pallida in its physiological properties but differs from it in the assimilation of potassium nitrate as the sole source of nitrogen. However, none of the enzyme patterns of the type strain (Rhodotorula araucariae YK 161) were similar to the enzyme patterns of Rhodotorula pallida, but they did resemble those of Rhodosporidium dacryoidum. Mating was not observed between strain YK 161 and any of the mating types of Rhodosporidium dacryoidum.

Rhodotorula acheniorum was isolated from strawberries and was described by Buhagiar and Barnett (8) under the name Sterigmatomyces acheniorum. It was transferred to the genus Rhodotorula by Rodrigues de Miranda (39) because sterigmata were not observed. The assimilation patterns of the carbon sources and the enzymatic patterns were similar to those of $R h o$ - 
dotorula glutinis groups 1 and 4. Thus, Rhodotorula acheniorum can be regarded as a synonym of Rhodotorula glutinis.

Rhodotorula sinensis, which was isolated from diseased pears taken from cold storage in Peking, China, was named and described by Lee (28). von Arx et al. (49) stated that this species could be Rhodosporidium capitatum. The enzymatic patterns of Rhodotorula sinensis were not similar to those of Rhodosporidium capitatum, but they resembled those of Rhodosporidium infirmo-miniatum. However, whether mating occurs between Rhodotorula sinensis YK 165 and each of the alleles in Rhodosporidium infirmo-miniatum is not yet clear.

Implication of electrophoretic patterns of enzymes in yeast taxonomy. We found that comparisons of the electrophoretic patterns of enzymes provided a reliable method for identifying and classifying species of yeasts. Clearly, identical enzyme mobility is not always proof of structural similarity. However, differences in mobility are likely to be reflections of primary structural differences in enzymes. Therefore, in comparing strains of yeasts, the electrophoretic patterns of many enzymes should be examined.

It is interesting that possible haploid mating partners were detected by comparing the enzymatic patterns of various strains and that such strains did indeed cross with the known haploid mating type strains. We conclude that this zymogram technique can contribute to the chemotaxonomy of yeasts. Moreover, we believe that further investigations between anamorphs and teleomorphs will be required in the genera Sporobolomyces and Cryptococcus, which are related to the basidiomycetes on the basis of their enzymatic patterns.

\section{ACKNOWLEDGMENTS}

We thank S. Goto (Yamanashi University, Kofu, Japan), K. Tsubaki (Tsukuba University, Tsukuba, Japan), and D. Yarrow (Centraalbureau voor Schimmelcultures, Yeast Division, Delft, The Netherlands) for their encouragement and invaluable suggestions. We also thank $\mathrm{T}$. Iijima (Institute for Fermentation, Osaka, Japan), K. Yamada (Central Research Laboratories, Ajinomoto Co., Inc., Kawasaki, Japan), A. Kochová-Kratochvilová (Institute of Chemistry of the Slovak Academy of Sciences, Bratislava, Czechoslovakia), and K. A. Wegener (Sektion Biologie der Ernst-Moritz-Arndt-Universität, Greifswald, Germany) for supplying cultures.

\section{REPRINT REQUESTS}

Address reprint requests to: Dr. K. Komagata, Institute of Applied Microbiology, University of Tokyo, Yayoi 1-1-1, Bunkyo-ku, Tokyo 113, Japan.

\section{LITERATURE CITED}

1. Banno, I. 1963. Preliminary report on cell conjugation and mycelial stage in Rhodotorula yeasts. J. Gen. Appl. Microbiol. 9:249-251.

2. Banno, I. 1967. Studies on the sexuality of Rhodotorula.
J. Gen. Appl. Microbiol. 13:167-196.

3. Baptist, J. N., and C. P. Kurtzman. 1976. Comparative enzyme patterns in Cryptococcus laurentii and its taxonomic varieties. Mycologia 68:1195-1203.

4. Baptist, J. N., M. Mandel, and R. L. Gherna. 1978. Comparative zone electrophoresis of enzymes in the genus Bacillus. Int. J. Syst. Bacteriol. 28:229-244.

5. Bassiri, A., and I. Rouhani. 1977. Identification of broad bean cultivars based on isoenzyme patterns. Euphytica 26:279-286.

6. Berchev, K., and K. Izimirov. 1967. Isoenzymes of some oxidoreductases in the Candida genus as a basis of species identification after electrophoresis. Experientia 23:961-962.

7. Bicknell, J. N., and H. C. Douglas. 1970. Nucleic acid homologies among species of Saccharomyces. J. Bacteriol. 101:505-512.

8. Buhagiar, R. W. M., and J. A. Barnett. 1973. Sterigmatomyces acheniorum species nova, a yeast from strawberries. J. Gen. Microbiol. 77:71-78.

9. Davis, B. J. 1964. Disc electrophoresis. II. Method and application to human serum proteins. Ann. N. Y. Acad. Sci. 121:404-427.

10. Fell, J. W. 1970. Yeasts with heterobasidiomycetous life cycles, p. 49-66. In D. G. Ahearn (ed.), Recent trends in yeast research, vol. 1. Georgia State University, Atlanta.

11. Fell, J. W., I. L. Hunter, and A. S. Tallman. 1973. Marine basidiomycetous yeasts (Rhodosporidium spp. n.) with tetrapolar and multiple allelic bipolar mating systems. Can. J. Microbiol. 19:643-657.

12. Gorin, P. A., and J. F. T. Spencer. 1970. Proton magnetic resonance spectroscopy. An aid in identification and chemotaxonomy of yeasts. Adv. Appl. Microbiol. 13:25-89.

13. Goto, S., K. Ohwada, and K. Yamasato. 1974. Identification of yeasts isolated from seawater and sediment in Aburatsubo inlet. J. Gen. Appl. Microbiol. 20:317322.

14. Goto, S., and J. Sugiyama. 1968. Studies on Himalayan and some asporogenous yeasts. J. Jpn. Bot. 43:102-108.

15. Goto, S., and J. Sugiyama. 1970. Studies on Himalayan yeasts and molds. IV. Several asporogenous yeasts, including two new taxa of Cryptococcus. Can. J. Bot. 48:2097-2101.

16. Goto, S., J. Sugiyama, and H. Iizuka. 1969. A taxonomic study of Antarctic yeasts. Mycologia 61:748-774.

17. Goto, S., K. Yamasato, and H. Iizuka. 1974. Identification of yeasts isolated from the Pacific Ocean. J. Gen. Appl. Microbiol. 20:309-316.

18. Goto, S., and I. Yokotsuka. 1962. Classification of the film yeasts maintained in Japan. I. Genus Pichia. Bull. Res. Inst. Ferment. Yamanashi Univ. 9:71-77.

19. Grinbergs, J., and D. Yarrow. 1970. Rhodotorula araucariae sp. n. Antonie van Leeuwenhoek J. Microbiol. Serol. 36:450-457.

20. Hasegawa, T. 1965. A report on the taxonomy of red to orange Rhodotorula. Annu. Rep. Inst. Ferment. Osaka 2:1-25.

21. Hasegawa, T., I. Banno, and S. Yamauchi. 1960. A taxonomic study on the genus Rhodotorula. I. The subgenus Rubrotorula nov. subgen. J. Gen. Appl. Microbiol. 5:200-212.

22. Hasegawa, T., I. Banno, and S. Yamauchi. 1960. A taxonomic study on the genus Rhodotorula (continued). J. Gen. Appl. Microbiol. 6:196-215.

23. Hirosawa, N., and H. Takada. 1969. Salt susceptibility of Rhodotorula glutinis var. salinaria isolated from salt farm in Japan. Trans. Mycol. Soc. Jpn. 10:35-39.

24. Iizuka, H., and S. Goto. 1965. Microbiological studies on petroleum and natural gas. VIII. Determination of yeasts isolated from oil-brines and related materials. J. Gen. Appl. Microbiol. 11:331-337.

25. Johnson, M. L. 1974. Mammals, p. 26-44. In C. A. Wright 
(ed.), Biochemical and immunological taxonomy of animals. Academic Press, Inc., London.

26. Keller, F. T., and K. A. Wegener. 1977. Taxonomische Untersuchungen an sexuellen Stämmen von Rhodotorula glutinis (Fres.) Harrison, $R h$. aurantiaca (Saito) Lodder und Rh. rubra (Demme) Lodder. Zentralbl. Bakteriol. Parasitenkd. Infektionskr. Hyg. Abt. 2 132: 25-43.

27. Kocková-Kratochvilová, A., and Z. Holan. 1976. Cytological chemical changes in cell walls of Rhodotorula gracilis. III. Characteristics and life cycle of the yeast. Folia Microbiol. 21:83-89.

28. Lee, M.-H. 1974. A new species of yeast: Rhodotorula sinensis Lee sp. nov. Acta Microbiol. Sin. 14:143-156.

29. Marcilla, J., E. Feduchy, and J. M. Gomes. 1945. Trab. Inst. Cajal Invest. Biol. 3:161. (As cited in J. Lodder (ed.), The yeasts. A taxonomic study. North-Holland Publishing Co., Amsterdam.

30. Nakase, T., and K. Komagata. 1968. Taxonomic significance of base composition of yeast DNA. J. Gen. Appl. Microbiol. 14:345-357.

31. Nakase, T., and K. Komagata. 1971. Significance of DNA base composition in the classification of yeast genera Cryptococcus and Rhodotorula. J. Gen. Appl. Microbiol. 17:121-130.

32. Nakase, T., and K. Komagata. 1971. DNA base composition of some species of yeasts and yeast-like fungi. J. Gen. Appl. Microbiol. 17:363-369.

33. Newell, S. Y., and J. W. Fell. 1970. The perfect form of a marine-occurring yeast of the genus Rhodotorula. Mycologia 62:272-281.

34. Newell, S. Y., and I. L. Hunter. 1970. Rhodosporidium diobovatum $\mathrm{sp} . \mathrm{n}$., the perfect form of an asporogenous yeast (Rhodotorula sp.). J. Bacteriol. 104:503-508.

35. Okunishi, M., K. Yamada, and K. Komagata. 1979 Electrophoretic comparison of enzymes from basidiomycetes in different stages of development. J. Gen. Appl. Microbiol. 25:329-334.

36. O'Rourke, F. J. 1974. Fish, p. 254-267. In C. A. Wright (ed.), Biochemical and immunological taxonomy of animals. Academic Press, Inc., London.

37. Phaff, H. J., and D. G. Ahearn. 1970. Genus Rhodotorula Harrison, p. 1187-1223. In J. Lodder (ed.), The yeasts, a taxonomic study. North-Holland Publishing Co., Amsterdam.

38. Phaff, H. J., and C. W. Price. 1977. Strength and weakness of traditional criteria in the systematics of yeasts as revealed by nuclear genome comparison, p. 1-12. In S. Paglialunga and N. S. Scrimshaw (ed.), Single cell protein $\rightarrow$ safety for animal and human feeding. Pergamon Press, London.

39. Rodrigues de Miranda, L. 1975. Two new species of the genus Sterigmatomyces. Antonie van Leeuwenhoek J. Microbiol. Serol. 41:193-199.

40. Shechter, Y. 1972. Comparative electrophoresis and numerical taxonomy of some Candida species. Mycologia $64: 841-853$.
41. Siciliano, M. J., and C. R. Shaw. 1976. Separation and visualization of enzymes on gels, p. 185-209. In I. Smith (ed.), Chromatographic and electrophoretic techniques, 4th ed., vol. 2. William Heinemann Medical Books Ltd., London.

42. Stephen, W. P. 1974. Insects, p. 305-324. In C. A. Wright (ed.), Biochemical and immunological taxonomy of animals. Academic Press, Inc., London.

43. Storck, R., C. J. Alexopoulos, and H. J. Phaff. 1969. Nucleotide composition of deoxyribonucleic acid of some species of Cryptococcus, Rhodotorula, and Sporobolomyces. J. Bacteriol. 98:1069-1072.

44. Sugiyama, J., and S. Goto. 1967. Coprophilous fungi from Karakorum I. J. Jpn. Bot. 42:75-84.

45. Sugiyama, J., and S. Goto. 1969. Mycoflora in core samples from stratigraphic drillings in middle Japan. IV. The yeast genera Candida Berkhout, Trichosporon Behrend, and Rhodotorula Harrison from core samples. J. Fac. Sci. Univ. Tokyo Sect. 3 10:97-116.

46. Tsuchiya, T., Y. Fukuzawa, S. Amemiya, M. Yonezawa, and K. Suzuki. 1957. Serological classification of the genus Rhodotorula. Yokohama Med. Bull. 8: 215-224.

47. Tsuchiya, T., Y. Fukuzawa, and S. Kawakita. 1965. Significance of serological studies on yeasts. Mycopathol. Mycol. Appl. 26:1-15.

48. van der Walt, J. P. 1970. Criteria and methods used in classification, p. 34-113. In J. Lodder (ed.), The yeasts, a taxonomic study. North-Holland Publishing Co., Amsterdam.

49. von Arx, J. A., L. Rodrigues de Miranda, M. T. Smith, and D. Yarrow. 1977. The genera of yeasts and the yeast-like fungi, p. 1-42. In Studies in mycology, vol. 14. Centraalbureau voor Schimmelcultures, Institute of the Royal Netherlands Academy of Arts and Sciences, Baarn.

50. Yamada, Y., Y. Kanematsu, M. Ohashi, and K. Kondo. 1973 . On the partly reduced coenzyme $Q$ isolated from "Rhodotorula lactosa" IFO 1058 and its relation to the taxonomic position. Agric. Biol. Chem. 37:621-628.

51. Yamada, Y., and K. Kondo. 1972. Taxonomic significance of coenzyme $\mathbf{Q}$ system in yeasts and yeast-like fungi, p. 363-373. In A. Kocková-Kratiochvilová and E. Minárik (ed.), Proceedings of the 1st Specialized International Symposium on Yeasts. Publishing House of the Slovak Académy of Sciences, Bratislava.

52. Yamada, Y., and K. Kondo. 1973. Coenzyme Q system in the classification of the yeast genera Rhodotorula and Cryptococcus and the yeast-like genera Sporobol. omyces and Rhodosporidium. J. Gen. Appl. Microbiol. 19:59-77.

53. Zimmerman, R. J., and W. E. Kloos. 1976. Comparative zone electrophoresis of esterases of Staphylococcus species isolated from mammalian skin. Can. J. Microbiol. 21:771-779. 